\title{
From “Leader to Pariah"? On the Dutch Restitutions Committee and the inclusion of the public interest in assessing Nazi-spoliated art claims
}

\author{
Tabitha I. Oost (10) \\ Department of Constitutional and Administrative Law, Faculty of Law, University of Amsterdam, \\ Amsterdam, The Netherlands \\ Email: t.i.oost@uva.nl
}

\begin{abstract}
This article considers the recent and vigorous critique of the Dutch restitution policy on Nazi-looted art in connection with the inclusion of what has been termed the "public interest" in the applicable substantive assessment framework. This assessment framework is entirely based on morally induced policy rules, and it allows the Dutch Restitutions Committee to advise on requests for restitution based on a weighing of interests, including the significance of the work to a museum or public art collection. Although one might question the appropriateness of such interests in a framework designed to remedy historic injustices, it remains to be seen whether this critique is entirely justified. Recent recommendations issued by the Dutch Restitutions Committee indicate that it takes a generous, rather than strict, approach when dealing with requests for restitution. All in all, it seems that both institutional and substantive vulnerability are inevitable if one embarks on a morally induced framework based on mere policy rules rather than legal rules.
\end{abstract}

Keywords: looted art; restitution; World War II; Nazi-spoliated art; restitution committees

\section{Introduction}

Ever since the Dutch Restitutions Committee (RC) was established in 2001 (formally known as the Advisory Committee on the Assessment of Restitution Applications for Items of Cultural Value and the Second World War), the Dutch restitution policy on Nazilooted art has consistently received international praise for its results in dealing with restitution requests. ${ }^{1}$ Over the past few years, however, (international) public opinion has begun to change. At a conference held in November 2018 to mark the twentieth anniversary of the Washington Principles, former US Ambassador Stuart Eizenstat, the spiritual father of those Principles, expressed rather critical views of the Dutch

\footnotetext{
${ }^{1}$ The Netherlands was listed in 2014 as one of the countries that had made "major progress" toward implementing the Washington Principles. See Fisher and Weinberger 2014. Washington Principles on NaziConfiscated Art, 3 December 1998, https://www.state.gov/washington-conference-principles-on-nazi-confis cated-art/ (accessed 15 March 2021).

(c) The Author(s), 2021. Published by Cambridge University Press on behalf of the International Cultural Property Society. This is an Open Access article, distributed under the terms of the Creative Commons Attribution licence (http://creativecommons.org/ licenses/by/4.0/), which permits unrestricted re-use, distribution, and reproduction in any medium, provided the original work is properly cited.
} 
restitution policy on Nazi-looted art. $^{2}$ These critical comments were prompted by the RC's binding opinion issued just a month earlier in the case of the Lewenstein heirs, which concerned a painting by Wassily Kandinsky owned by the municipality of Amsterdam and on display at the Amsterdam Stedelijk Museum. ${ }^{3}$ The RC decided in favor of the municipality on the basis of a weighing of interests; the significance of the painting to the collection of the museum outweighed the interest of the heirs. ${ }^{4}$ According to Stuart Eizenstat, this binding opinion was a "step back" in the leading role that the Netherlands played after 2001 in the field of restitution of Nazi-looted art. ${ }^{5}$ A vigorous debate followed not only within, but also beyond, Dutch borders, which focused on the inclusion of the interest of the museum and the relevance of a particular work to public art collections within the applicable substantive policy framework. ${ }^{6}$ It is underlined here that, in the context of this article, the public interest is understood to encompass either the interest of the museum in terms of retaining its collection or the relevance of a particular work to public art collections and/or the culmination of the two. Since museums, whether private or public, serve the essential functions of preservation and allow public access to cultural objects, their interest coincides with the public interest. ${ }^{7}$ The public interest thus aligns with John Merryman's argument on the existence of a public interest in cultural property in terms of preservation and access. ${ }^{8}$

With respect to the debate, the claimants, their legal representatives, the claimant organizations, and members of the Jewish community assert that the Netherlands, over time, lost sight of the interests of the victims. ${ }^{9}$ Proponents of the current arrangements Fred Hammerstein, for one (that is, the now former chairman of the RC) - have argued the exact opposite, emphasizing that the interest of the victim is paramount in dealing with

2 “20 Years Washington Principles: Roadmap for the Future," 26-28 November 2018, organized by the German Lost Art Foundation, https://www.kulturgutverluste.de/Content/02_Aktuelles/EN/Foundation-Events/2018_20years-washington-principles/Specialist-Conference-20-Years-Washington-Principles-Roadmap-for-the-Future.html (accessed 15 March 2021); (Washington Principles).

${ }^{3}$ The painting was acquired by the Amsterdam City Council in 1940 as an addition to the collection of the Amsterdam Stedelijk Museum.

${ }^{4}$ Binding Opinion Regarding the Dispute about Restitution of the Painting Painting with Houses by Wassily Kandinsky, currently in the possession of Amsterdam City Council, RC 3.141, 22 October 2018 (Lewenstein/ Amsterdam City Council Claim).

${ }^{5}$ Daniel Boffey, quoting Stuart Eizenstat, in "Dutch Art Panel's Ruling against Jewish Family Criticized as 'Step Back,"” The Guardian, 5 December 2018.

${ }^{6}$ For international critique, see Kia Vahland, “Zu schön, um es zurückzugeben," Süddeutsche Zeitung, 5 November 2018; Noah Charney, "20 Years On, It's Time to Admit Our Rules for Handling Nazi-Looted Art Have Failed," The Observer, 20 November 2018; Catherine Hickley, "Dutch Policy on Nazi-loot Restitutions under Fire," The Art Newspaper, 21 December 2018. Specifically on the Lewenstein/Amsterdam City Council Claim, see Marsha Lederman, “'A Flagrant Insult': Kandinsky Painting Won't Be Returned to Jewish Heirs after 1940 Sale during Nazi Occupation," Globe and Mail, 12 November 2018.

${ }^{7}$ In this regard, see the International Council on Museum's definition of museums where it relates to a museum as an institution "in service of society" and being "open to the public" in its role in exhibiting tangible and intangible heritage of humanity for the purposes of education study and enjoyment." For the definition, see https://icom.museum/en/resources/standards-guidelines/museum-definition/ (accessed 15 March 2021).

${ }^{8}$ Merryman 1989,360-61; Merryman, Elsen, and Urice 2007, 142. In the same vain, see Casini 2011,375, where he mentions the "publicness" as one of the two common features ascribed to cultural property meaning that cultural property is "public because it must be accessible to the public and known."

9 This article's title is in part derived from Wesley Fisher and Anne Webber's, "Van leider naar paria? Nederland herzie beleid roofkunst!" NRC Handelsblad (NRC), 8 December 2018; Gert Jan van den Bergh, "Nederland is met roofkunst op de verkeerde weg," NRC, 14 December 2018; Emile Schrijver, "Roofkunst is meer dan een juridische zaak. Erken Emoties," NRC, 27 December 2019; Gerard Aalders, "Roofkunst terugkrijgen wordt steeds moeilijker zonder 'hard bewijs," Volkskrant, 18 December 2018; see also Tabitha Oost, "Maak de Restitutiecommissie minder kwetsbaar," Volkskrant, 4 January 2019. 
these claims. ${ }^{10}$ The critical voices have by no means faded into the background. ${ }^{11}$ Recently, an advisory committee created to evaluate the Dutch restitution policy, also known as the Kohnstamm Committee after its chair, Jacob Kohnstamm, also expressed critical views. ${ }^{12}$ When this article went to press, the minister of Education, Culture and Science gave an initial response stating that government would adopt the Kohnstamm Committee's recommendations, heralding a more favorable approach for claimants. A definitive reaction will follow this summer, but a "renewed" assessment framework has been announced. ${ }^{13}$ It is emphasized here that this article's focus is on the currently applicable policy, not in the least since the exact ramifications of this renewed policy are yet unknown. ${ }^{14}$ However, it is pointed out that the public interest and the weighing of interests, for that matter, will be largely excluded from the "renewed" assessment framework. ${ }^{15}$

I have argued elsewhere that the above-mentioned criticism relates to a predicament that committees such as the RC find themselves in, caused by a paradigm shift in dealing with Nazi-related injustices in general. ${ }^{16}$ At around the turn of the millennium, renewed

\footnotetext{
${ }^{10}$ Fred Hammerstein, "Bij Roofkunst staat het belang van het slachtoffer altijd voorop," NRC, 10 December 2018; see also Sandra Kooke, in an interview with Fred Hammerstein, Sandra Kooke, "Is de internationale kritiek op hoe Nederland omgaat met roofkunst terecht?" Trouw, 3 December 2018; Evelien Campfens, former secretary RC, "Nederland gaat gewetensvol om met roofkunst," NRC, 18 December 2019.

11 “Jewish Family Accuses Amsterdam Museum of 'Bias' over Kandinsky Ownership," Daily Telegraph, 18 January 2020; on another claim concerning a Kandinsky on display at the Van Abbe Museum in Eindhoven, see "Jewish Family Complains about Committee That Rules on Nazi-looted Art, Dutch News, 19 March 2020, https://www.dutchnews.nl/ news/2020/03/jewish-family-complains-about-committee-that-rules-on-nazi-looted-art/ (accessed 15 March 2021); see also Binding Opinion Regarding the Dispute about Restitution of the Painting Blick auf Murnau mit Kirche, by Wassily Kandinsky, Currently in the Possession of Eindhoven City Council, RC 3.162, 29 January 2018 (Lipmann-Stern/ Eindhoven City Council).

${ }^{12}$ Kohnstamm Committee 2020. Fred Hammerstein, who resigned from the RC per 1 December 2020, later attributing this action to the Kohnstamm report once it was published. For his critical views on the Kohnstamm report, see Hammerstein 2021.

${ }^{13}$ Letter from the Minister of Education Culture and Science to the Lower House, Doc. 2021D09968, 12 March 2021, Kamerstukken II (Parliamentary Papers) 2020-21, 25839, no. 48 (Letter from the Minister to the Lower House 2021). It appears that the phased response of the minister is connected to further developments in the Kandinsky claim. In a letter dated letter of 19 February 2021, the municipality of Amsterdam, despite a 16 December 2020 judgment of the Amsterdam municipal district court confirming the RC's Lewenstein/ Amsterdam City Council binding opinion, already announced its willingness to follow the Kohnstamm's report and expressed the wish to reassess the claim of the Lewenstein heirs. The minister's recent 12 March 2021 letter clarified that the RC can indeed reassess a binding opinion in case of mutual agreement of the parties involved. Letter from the Minister to the Lower House 2021, 6. See also Letter of the Board of Mayor and Aldermen to the Amsterdam Municipal Council, https://amsterdam.raadsinformatie.nl/modules/1/Berichten\%20uit\%20het\%20college/651069 (accessed 15 March 2021) (Letter of the Board of Mayor and Aldermen 2021). For the judgment, see Plaintiffs v. Municipality of Amsterdam, ECLI:NL:RBAMS:2020:6277 (District Court Amsterdam, 16 December 2020).

${ }^{14}$ Both the Kohnstamm Committee's report and the Letter from the Minister to the Lower House 2021 were issued after this article was submitted and accepted for publication. Although these documents could only provisionally be taken into account in this article, they do not affect its main findings or the thrust of its overall argument on the public interest.

${ }^{15}$ The RC's analysis should focus on the following two aspects: "highly plausible" ownership and "sufficiently plausible" involuntariness of the loss. The weighing of interests practice of the past years should be abolished in so far as the efforts of the former owner to retrieve the object after World War II and the interest of the current owner/ public interest are excluded from an assessment. When a current owner, however, asserts a good faith acquisition, the RC may still award "unconditional restitution" but "may" also resort to mediatory solutions (solutions other than restitution) - it is not clear how this choice between different possible solutions must be made. The minister's letter furthermore clarified that the Dutch state will refrain from asserting a good faith acquisition and indicated a similar willingness in the lower governments (municipalities and provinces) to do so. That said, it is still uncertain how this will play out in practice. Letter from the Minister to the Lower House 2021, 6; Kohnstamm Committee 2020, 34.

${ }^{16}$ Oost 2018.
} 
attention for the atrocities of World War II and its detrimental effects on those persecuted by the Nazis was increasingly considered to "challenge" the traditional legalist paradigm. ${ }^{17}$ The legalist paradigm - marked by a statute of limitations, rules on prescription, and evidentiary standards, guided by principles of legal certainty and foreseeability - fell short when it came to remedying the injustices of the past. Throughout Europe, a shift in dealing with these Nazi-related injustices was visible, where the traditional legalist paradigm moved to the background to make way for a morally induced approach where "mere" membership in a category of victims could lead to "lump sum" compensation. ${ }^{18}$ For the specific category of Nazi-looted cultural assets, therein lies the rub. As restitution is still considered the primary remedy in connection with looted cultural assets, ${ }^{19}$ the advisory committees established to deal with claims relating to cultural assets still have to provide an individualized, semi-legal assessment on the possible restoration of ownership of a formerly owned specific object, although now in a low-threshold procedure governed by open norms, while restitution is situated as a means to right past wrongs and is ascribed a broader meaning than simply restoring the situation ex ante. Rendering decisions in a context aimed at undoing grave injustices has proved difficult over time in the absence of clear substantive rules in an open procedure, as doubts about these committees are easily raised in terms of a general lack of transparency in the decision-making process, their independence, and their impartiality. It therefore makes these committees vulnerable to criticism, which touches upon the very essence of their raison d'etre: remedying historic injustices for victims of the Nazi regime.

This article is intended to build on this argument. The focus lies specifically on the critique and consequent discussion emanating from the Lewenstein/Amsterdam City Council claim. To this end, the article will start by addressing the mandate of the RC, with an emphasis on the origins of the inclusion of the public interest in the RC's assessment framework. Then the Lewenstein/Kandinsky case will be considered. The two main questions that this article seeks to answer are subsequently discussed: Is Dutch restitution policy in regard to the position of the claimant worse than in certain other countries and has the claimant's perspective indeed been forced to the background over time in Dutch restitution policy? To answer these questions, the Dutch restitution policy will be considered from an international comparative perspective. A closer look into a few recent cases dealt with by the RC will then follow, again, where possible, from a comparative perspective. It turns out that the claimant's situation in the Netherlands is not as dire as some have claimed.

\section{The Dutch restitution policy: A patchwork of rules}

The origins of the RC are closely connected to the renewed international and national attention for the fate of Jewish assets during and after World War II. ${ }^{20}$ In regard to the specific category of Nazi-looted art, the so-called "heirless collections" ${ }^{21}$ or objects residing in public hands led various European governments including the Dutch government to (re-)open the possibility for former owners and their heirs to claim those objects. ${ }^{22}$ In doing

\footnotetext{
${ }^{17}$ Neumann and Thompson 2015, 10-11.

${ }^{18}$ On the various different compensatory schemes in Austria, France, Switzerland, and the Netherlands, see Unfried 2014, 462; Oost 2018, 144-45.

19 O’Donnell 2010, 55; Woodhead 2014, 128; 2016, 386; Campfens 2015, 37; Oost 2018, 142.

${ }^{20}$ See generally Bazyler and Alford 2006, 3; O’Donnell 2011, 50-51.

${ }^{21}$ Campfens 2014, 81, referring to "heirless" art collections. For key publications raising awareness in this regard, see Nicolas 1994; Feliciano 1995; Petropoulos 1996.

${ }^{22}$ Similar initiatives to this end were taken in Austria, France, Germany, and England. For a recent overview, see Woodhead 2019; see also Oost 2012; Marck and Muller 2015.
} 
this, most European countries recognized the fruitlessness of litigation for claimants due to legal barriers such as statutes of limitation and evidentiary standards, which is emphasized in the 1998 international, but legally non-binding, document known as the Washington Principles. ${ }^{23}$ In November 2001, the Dutch government made the pragmatic decision to embark on a policy-induced approach rather than a strictly legal one. ${ }^{24}$ It was the RC that came to embody this decision. ${ }^{25}$

\section{A flexible policy shaped by its national history and context}

It is important to realize that the RC's mandate and its rationale emanates, for the most part, from the perceived need to act on the so-called Nederlands Kunstbezit Collectie (NK Collection). ${ }^{26}$ In the years prior to the establishment of the RC, much of the discussion on the fate of Jewish assets focused on this NK Collection residing with the Dutch state, "inherited" from a special legal system of restoration of rights enacted in the Netherlands in the years immediately following World War II. ${ }^{27}$ The collection consisted of roughly 4,000 objects that could not be, or were not, returned in the course of this first "round" of restitution ${ }^{28}$ that was designed to undo the adverse impact of the years of German occupation on the Dutch economy and citizens. ${ }^{29}$ The renewed attention for the persecuted

\footnotetext{
${ }^{23}$ Washington Principles.

${ }^{24}$ Oost 2018, 148-49.

${ }^{25}$ Besluit Adviescommissie Restitutieverzoeken cultuurgoederen en Tweede Wereldoorlog, Ministerial Order
} no. WJZ/2001/45374(8123), Dutch Government Gazette (Staatscourant), no. 248, 21 December 2001 (Establishing Decree 2001). The Establishing Decree has been altered twice, on 14 July 2012 and again on 20 September 2018. For the latest change in 2018, see Besluit van de Minister van Onderwijs, Cultuur en Wetenschap en de Minister voor Basis- en Voortgezet Onderwijs en Media van 20 september 2018, no. 1381345 tot wijziging van het Besluit adviescommissie restitutieverzoeken cultuurgoederen en Tweede Wereldoorlog in verband met de oprichting van een Expertisecentrum Tweede Wereldoorlog en Restitutieverzoeken, alsmede enkele technische aanpassingen, Dutch Government Gazette (Staatscourant) no. 54468, 1 October 2018 (for an unauthorized translation of the consolidated version of the Decree, see https://www.restitutiecommissie.nl/sites/default/files/Decree-textvalid from2-Oct-2018.pdf (accessed 15 March 2021).

${ }^{26}$ Establishing Decree 2001, Art. 2, sub. 1; see also Campfens 2014, 81; Oost 2018, 148. The discussion in this paragraph goes along the same lines as the analysis in Oost 2018,146-54. It is, however, necessary for the purpose of this article to briefly recall the Dutch institutional structure as well as the developments over time as the debate on the public interest originates in the institutional structure.

${ }^{27}$ This legislation was rather exceptional. The legislature in the Netherlands is a compound organ and an act of Parliament requires the consent of both Parliament and government ex Article 81 Grondwet (Dutch Constitution). After the German invasion of the Netherlands in May 1940, the Dutch government, however, had fled to London, which rendered the ordinary legislative procedure impossible. The Dutch government in exile resorted to emergency powers, and, until 20 November 1945, all Dutch legislation was issued in the form of royal decrees or so-called statutory orders. These decrees were presumed to have the same status as acts of parliament and amounted to a complex system that governed the restoration of rights. In short, it provided for special executive institutions as well as a special judiciary exclusively competent to rule on disputes concerning the restoration of rights. For the purposes of this article, it would go too far to discuss this in depth. On this system in general, see, critically, Veraart 2005; Oost 2018, 147n61.

${ }^{28}$ Veraart (2016, 967-68), using "rounds" to designate postwar and present-day efforts in restoring legal rights in the Netherlands and France. Oost 2018, 146.

${ }^{29}$ It was the Dutch interpretation of the 1943 Inter-Allied Declaration that promulgated the reversal of the Nazi deprivation of property, recognizing particularly the cultural plunder throughout Europe. The Inter-Allied Declaration is predominantly considered to announce a mere general norm of restitution in interstate terms, and it led to the enactment of various individual post-World War II restitution laws in the jurisdictions of various European countries. On the status of the Inter-Allied Declaration under international law, see O'Donnell 2011, 60; Peters 2012, 145-46; Woodhead 2014, 115. For an analysis of the Inter-Allied Declaration and the different post World War II restitution laws, see Campfens 2015, 16-26. 
groups, particularly those of Jewish descent and their belongings, increasingly caused the NK Collection to be considered "tainted" due to a possible Nazi-looting background. ${ }^{30}$ At that point in time, the NK Collection was indeed cloaked in a "haze of secrecy" 31 as it was unclear whether, and to what extent, objects in the collection had been formerly owned by individuals belonging to Nazi-persecuted groups.

Around the turn of the millennium, a government-installed advisory committee, known as the Ekkart Committee after its chair, Rudi Ekkart, played an important role in clarifying the provenance of this NK Collection. ${ }^{32}$ The main conclusion of the Ekkart Committee was that the NK Collection resulted from the "formalistic, bureaucratic, cold, and often even heartless" 33 manner in which the Dutch post-World War II system of restoration of rights was executed. The Ekkart Committee's conclusion played an important role in triggering a different approach to the matter of Nazi-looted art in light of the perceived need to take account of the victims' perspective. A strict, legal approach, as applied in the first "round" of restitution, which was infused with egalitarianism such that every individual was treated the same regardless of the atrocities endured during World War II, was increasingly considered undesirable when addressing historic injustices of the past. ${ }^{34}$

When the RC's Establishing Decree, a mere ministerial order, was presented to Parliament in 2001, it demonstrated that the Dutch government had let go of its initial narrow focus regarding the NK Collection. ${ }^{35}$ The Dutch government acceded to Parliament's wish for a generous and comprehensive approach. ${ }^{36}$ This resulted in a two-pronged task. The first task of the RC was to issue basic advisory recommendations to the minister on requests for restitution concerning the entire Dutch national art collection. ${ }^{37}$ At that time, this task was subject to relaxed governmental guidelines, which largely depended on the three sets of

\footnotetext{
${ }^{30}$ Oost 2018, 148; see also Oost 2012, 180-81; Marck and Muller 2015, 75.

${ }^{31}$ Translation from "waas van onduidelijkheid." Letter from the State Secretary of Education Culture and Science to the Lower House, 20 May 1998, Kamerstukken II (Parliamentary Papers), 1997-98, 25013, 23.

${ }^{32}$ This committee was established in the fall of 1997 and formed part of the governments' endeavor to shed light on the fate of Jewish assets during and after the war. The Ekkart Committee was one of four government-installed committees around that time that researched the impact of the Nazi-looting campaign and the effectiveness of the Dutch system on the restoration of rights to undo the damage done during wartime. In chronological order, the other three committees were the Van Kemenade Committee (Contact Group for Second World War Funds Nazi-Gold), the Scholten Committee (Financial funds - securities, bank accounts, and insurance policies), and, lastly, the Kordes Committee (Liro archives/Jewish privately owned tangible goods such as jewelry, diamonds, and household effects). A fifth committee, the Van Galen Committee, focused on another aspect of World War II; it researched the financial consequences of the Japanese occupation of the former Dutch colonies in Asia, mainly Indonesia, and the fate of Indian funds. Oost 2018, 148 n66.

${ }^{33}$ Herkomst Gezocht/Origins Unknown 2006, 14, 28; Establishing Decree 2001, explanatory notes.

${ }^{34}$ For one, this had to do with the fact that the system foresaw in protection of the good faith purchasers. This could entail that a former owner would have to settle for financial compensation instead of restitution. For these and other reasons, Veraart considered the Dutch system on the restoration of rights to be flawed. See Veraart 2005, 68-72, 546-47; 2016, 9.

${ }^{35}$ Establishing Decree 2001, explanatory notes.

${ }^{36}$ Letter of the State Secretary to Parliament, 29 June 2001, Kamerstukken II (Parliamentary Papers), 2000-1, 25839 , no. 26, referring to a request from the Standing Committee for Education Cultural and Science requesting for a mediator after the English example set by the Spoliation Advisory Panel (SAP). Letter from the Standing Committee for Education Culture and Science to the Minister of Education Culture and Science, Doc. SC-01-33, 7 June 2001 (on file with the author) (Letter from the Standing Committee 2001).

${ }^{37}$ These recommendations are not legally binding upon the minister. To date, the minister has accepted all recommendations by the RC, albeit in the Goudstikker recommendation, restitution was awarded based on a different line of reasoning. See Recommendation Regarding the Application by Amsterdamse Negotiatie Compagnie NV in Liquidation for the Restitution of 267 Works of Art from the Dutch National Art Collection, RC 1.15, 19 December 2005, http://www.restitutiecommissie.nl/en/summary_rc_115.html (accessed 15 March 2021) (Goudstikker Recommendation).
} 
recommendations issued to that end by the Ekkart Committee. ${ }^{38}$ These relaxed guidelines implied, among other things, a reversal of the burden of proof on the involuntariness of the loss and relaxed standards regarding proof of ownership. ${ }^{39}$ It should be emphasized here that, as part of this generous approach, not only the "tainted" NK Collection, but also all objects in the Dutch National Art Collection, were made eligible for restitution based on the renewed and liberalized government guidelines, despite their disparate provenance. ${ }^{40}$

The RC's second task was to issue opinions on ownership disputes between the "original owner" and the "current possessor which is not the State of the Netherlands." ${ }^{41}$ This second task, now frequently referred to as the binding opinion procedure, was a second iteration of the generous approach. ${ }^{42}$ The task was added to the RC's mandate based on the request of Parliament to provide for a committee that could act as an "independent mediator in ownership disputes," following the English example set by the Spoliation Advisory Panel (SAP) in 2000. ${ }^{43}$ At that time, it was thought that the binding opinion procedure would be relevant for disputes between private individuals. ${ }^{44}$ Although both the RC's tasks are founded in the "involuntary loss of possession due to circumstances related to the Nazi regime," 45 a different set of substantive rules was to govern this second task: the principles of "reasonableness and fairness." The Establishing Decree of 2001 remained silent, however, on what such an assessment-based approach might entail, although it did give the RC, in Article 4(2), the possibility to "draw up regulations for further working methods." ${ }^{46}$

The overall aim of the decision of the government to change tack in 2001 was to provide for a claimant-friendly, low-threshold, and flexible procedure to facilitate former owners and their heirs, given "the advanced age of many of the interested parties." ${ }^{47} \mathrm{~A}$ "strict legal

${ }^{38}$ The policy framework concerning the Dutch National Art Collection is the result of a dialogue between the Dutch government and the Ekkart Committee. Oost 2018, 150n81; Lubina 2009, 299-312. Based on the Ekkart Committee's recommendations the Dutch restitution policy discerns between private individuals (Ekkart Recommendations 2001) and art dealerships (Ekkart Recommendations 2003). In 2004 the Ekkart Committee presented its final recommendations. The recommendations can be found at https://www.restitutiecommissie.nl/2001_instell ing_restitutiecommissie.html (accessed 15 March 2021) (Ekkart Recommendations).

${ }^{39}$ With respect to the presumption of involuntariness of loss, this applies to private individuals in Germany from 1933, Austria from 1938, and the Netherlands from the moment of the German invasion. See Ekkart Recommendations 2001, 3.

${ }^{40}$ The Dutch National Art Collection is primarily composed of acquisitions, bequests and gifts. The Ekkart Commitee's provenance research however indicated that apart from the NK-collection the Dutch National Art collection also contained "tainted" objects, which was illustrated by the so-called Lieberman case concerning a painting by Max Lieberman that ended up in the Groninger Museum. See extensively Muller 2001, 25.

${ }^{41}$ Establishing Decree 2001, Art. 2, sub 2.

${ }^{42}$ On the RC's website, the terms "binding opinions" and "binding expert opinions" are used alternately. For the latter reference, see "Recommendations," Restitutiecommissie.nl, n.d., https://www.restitutiecommissie.nl/en/ adviezen.html (accessed 15 March 2021). Campfens (2014) uses "binding expert opinion."

${ }^{43}$ Letter from the Standing Committee 2001.

${ }^{44}$ Establishing Decree 2001, explanatory notes to Art. 2, where reference is made to the wish to facilitate "particulieren" (private individuals) in a dispute.

${ }^{45}$ Establishing Decree 2001, Art. 2, subs 1,2.

${ }^{46}$ The explanatory notes of the Establishing Decree merely recall the motivation for this choice. Apart from noting the example of committees in other countries (mainly the SAP as well as "the express request of the Lower House of Parliament," no further information is shared on the actual remits of the mandate. Establishing Decree 2001, explanatory notes, Art. 2.

${ }^{47}$ Herkomst Gezocht/Origins Unknown 2006, 28. See also Letter of the State Secretary of Education Culture and Science, 29 June 2001, Kamerstukken II (Parliamentary Papers), 2000-1, 25839, no. 26, which contain the governments' first reaction on these first recommendations. 
approach" was "no longer acceptable." 48 Instead, an approach based on moral considerations was chosen to facilitate the restoration of former ownership rights, given the past atrocities during the years of the Nazi reign. ${ }^{49}$

\section{Introducing the "public interest": The 2007 Regulations for the Binding Opinion Procedure}

The choice for low-threshold and loosely structured proceedings to facilitate claimants has the obvious advantage of flexibility. And it is this flexibility that catalyzed a certain lack of clarity in the Dutch context. The fact is that, in the Netherlands, the applicable procedure, as well as the applicable substantive assessment framework, has been subject to various changes over time..$^{50}$ There was an important change relating to the RC's second task in the binding opinion procedure, with the public interest being introduced as an element of the committee's assessment yardstick. The rules relating to this procedure were published in 2007, six years after the establishment of the RC, in the so-called Regulations for Opinion Procedure. ${ }^{51}$ Only in 2006 were two cases brought before the RC concerning objects that were not held by the state, thus prompting further clarification of the principles of reasonableness and fairness. ${ }^{52}$ In 2007, therefore, the RC asserted the possibility granted in Article 4(2) of the Establishing Decree. Based on the Regulations for Opinion Procedure, claims relating to the second task of the RC were to be dealt with on the basis of a weighing of interests between the former and the current owners. The opinions resulting from this weighing of interests would be issued in the form of a legally binding settlement agreement based on Article 7:900 of the Dutch Civil Code. ${ }^{53}$ In regard to the relevant interests, the RC elucidated in Article 3 of the Regulations for Opinion Procedure that, among other things, it not only may take into account the "significance of the work to the former owner" but also consider the position of the current owner. Here, the possible good-faith acquisition of a work, the "significance" of a work to the current owner, and, generally, the "significance of a work to public art collections" may be included in the RC's weighing of interests. This weighing of interests went hand in hand with flexibility in terms of potential remedies. Whereas for the NK Collection a positive recommendation could only lead to restitution, based on the Regulations for Opinion Procedure, the RC could award any possible solution it deemed fit. ${ }^{54}$

It should be noted that the Regulations for Opinion Procedure were drafted in a time marked by "questions" that "gradually started emerging in the media about the legitimacy of returning looted items of cultural value." ${ }^{55}$ These questions related to the course of events

\footnotetext{
${ }^{48}$ Quoting the English translation of the Establishing Decree 2001, explanatory notes.

${ }^{49}$ Denominated as a shift in paradigms in dealing with Nazi-related injustices in Oost 2018, 142-45.

${ }^{50}$ The following analysis is not meant as an exhaustive overview of all changes that the Dutch policy has undergone.

${ }^{51}$ In 2007, the Regulations for Opinion Procedure for Opinion Procedure under Article 2, paragraph 2, of the Decree Establishing the Advisory Committee on the Assessment of Restitution Applications for Items of Cultural Value and the Second World War were created. A revised version was published on 28 November 2019. See Regulations Binding Expert Opinion Procedure, 28 November 2019, https://www.restitutiecommissie.nl/en/sys tem/files/Regulations2019.pdf (accessed 15 March 2021) (Regulations for Opinion Procedure).

${ }^{52}$ Until 2006, the cases dealt with by the RC exclusively concerned objects from the Dutch National Art Collection, mostly involving NK-objects. Advisory Committee on the Assessment of Restitution Applications for Items of Cultural Value and the Second World War 2006, 10-11.

${ }^{53}$ Regulations for Opinion Procedure, Art. 2, sub. 2. The RC can also promote a settlement between the parties however, yet, the RC has never been requested to act in this capacity.

54 The word "significance" (as a translation of the Dutch word "belang") follows from the English translation of Regulations for Opinion Procedure, Art. 3, sub. g. On possible solutions or remedies, see Oost 2018, 153; Regulations for Opinion Procedure, Art. 11.

${ }^{55}$ Advisory Committee on the Assessment of Restitution Applications for Items of Cultural Value and the Second World War 2007, 10.
} 
in one of the renowned Dutch high-profile claims, concerning the heirs of Jacques Goudstikker and the RC's Goudstikker Recommendation, ${ }^{56}$ which was issued in December 2005, giving rise to critique in the Netherlands. ${ }^{57}$ Based on the Goudstikker Recommendation, restitution of over 200 artworks was awarded to Marei von Saher, the rightful heir of art dealer Jacques Goudstikker. Marei von Saher consequently auctioned off large parts of the Goudstikker collection. ${ }^{58}$ Furthermore, von Saher had no consanguine relationship with the Goudstikkers, nor had she even known Jacques Goudstikker. She was the wife of Jacques Goudstikker's only son Edouard. ${ }^{59}$ In short, within the Netherlands, the moral value of restitution of looted artworks was publicly challenged because it led to the deaccessioning of artworks of value not only because of the financial consequences but also in view of Dutch cultural heritage. ${ }^{60}$ This concern about the latter's interest was consistent with, and enshrined in, the then applicable Cultural Heritage Preservation Act and, therefore, in the broader context of the protection of cultural objects, certainly no novelty. ${ }^{61}$ However, as mentioned above, the RC's second task was rather explicitly situated in the context of a dispute between private individuals and the guidance sought in the sphere of private law principles of reasonableness and fairness, which are also therefore logical. ${ }^{62}$ It thus remains to be seen whether the inclusion of this strong public connotation in the explanation of the principles of reasonableness and fairness was foreseen at the time of the establishment of the RC.

\section{The inclusion of the "public interest" in a changing landscape of applicable rules 63}

The choices made in the Regulations for Opinion Procedure did not give rise to concern; nor did the first binding opinions that were rendered on the basis of the Regulations in

\footnotetext{
${ }^{56}$ Goudstikker Recommendation.

${ }^{57}$ As mentioned, only the Goudstikker Recommendation was not followed by the state secretary. Restitution did take place, but it was based on the state secretary's own motivation. See "Summary," RC 1.15, 20 December 2005, restitutiecommissie.nl, http://www.restitutiecommissie.nl/en/summary_rc_115.html (accessed 15 March 2021).

${ }^{58}$ This was at least partially due to the high legal fees that Marei von Saher owed her lawyers. At the Christie's auction in April 2007, masterpieces such as Rivierlandschap met Veerpont from Salomon van Ruysdael previously on display at the Rijksmuseum and the portrait of Jean le Gouche, by Johannes Cornelisz Verspronck, previously on display at the Frans Hals Museum, were sold. Other sold items were by Jan van Goyen, Philips Koninck, Isaac van Ostade, Jacob van Oostsanen, Jacob van Ruisdael, Neri di Bicci, and Pietro Longhi. Numerous articles were published in various Dutch newspapers in this regard. See, for example, "Groot deel Goudstikkercollectie wordt geveild," Volkskrant, 22 February 2007; “Groot deel collectie Goudstikker op veiling Christie's,” NRC, 22 February 2007.

${ }^{59}$ It took Marei von Saher until 1997, a year after the death of her husband to learn, via the Dutch journalist Pieter den Hollander, about the Goudstikker collection. She and her husband, Jacques Goudstikker's son, never talked about the war with Goudstikker's widow, Jacques' mother and her mother in law, Dési Goudstikker-Von Halban. On this story, see extensively Den Hollander 2007; see also Henny de Lange, "De strijd van de erven Goudstikker," Trouw, 28 December 2006.

${ }^{60}$ It is noted here that the RC's recommendation also received legal criticism, mainly from Veraart, who argued that the RC ignored the fact that the Goudstikker claim had already been settled between 1945 and 1999 . These legal decisions seem the primary reason for the state secretary not to follow the RC's motivation in its recommendation for restitution. For the criticism, see Veraart 2010, 19-21.

${ }^{61}$ In a regime governed by Arts. 2, 3, 7 for movable property. The Cultural Heritage Preservation Act (Wet Behoud Cultuurbezit) is now subsumed in the Wet van 9 December 2015, houdende bundeling en aanpassing van regels op het terrein van cultureel erfgoed (Erfgoedwet), which came into force in 2016, Dutch Bulletin of Acts and Decrees (Staatsblad), no. 511, 18 December 2015 and no. 14, 12 January 2016. For an official English translation see https://www.cultureelerfgoed.nl/publicaties/publicaties/2016/01/01/heritage-act-2016 (accessed 15 March 2021) (Heritage Act).

${ }^{62}$ Establishing Decree 2001, explanatory notes, Art. 2.

${ }^{63}$ It bears repeating that the analysis in this section is based on currently applicable, and not future, policy.
} 
$2008{ }^{64}$ The binding opinions issued in 2013 in the case of the heirs of Jewish businessman Richard Semmel led to the first critical questions regarding the weighing of interests and, particularly, how the assertion of the public interest could play out. The criticism of the Semmel case was due, in part, to the fact that two separate assessment frameworks were in effect side by side. Already in 2009, the RC had issued its first positive recommendation for restitution to the Semmel heirs, who had requested restitution of an object in the NK Collection. According to the RC, Semmel had involuntarily lost possession of the object in 1933 in order to finance his flight from Germany to the Netherlands. ${ }^{65}$ When the Semmel heirs asked for restitution of four other objects a few years later, these requests were dealt with under the binding opinion procedure since the objects were not included in the Dutch National Art Collection but owned by foundations (museums) and municipalities. ${ }^{66}$ In two of these bindings opinions, the Semmel heirs' requests for restitution were rejected despite the fact that the circumstances of the loss of possession, which led to the 2009 positive restitution recommendation, were exactly the same. Since the RC had to weigh the relevant interests, it came to the conclusion that the objects in question were too vital to the collection to be returned; the interests of the heirs were superseded due to their weak emotional link to the claimed objects. ${ }^{67}$ This conclusion was not well received by the Semmel heirs; ${ }^{68}$ the mere location of an object meant that the work's significance to a publicly accessible art collection could outweigh the conclusion that a loss had been incurred due to Nazi persecutory measures. ${ }^{69}$

The confusion about the two separate assessment frameworks was an important factor in another substantial change being made to Dutch restitution policy. In 2012, the state secretary announced that there would be a phased unification of the policy ${ }^{70}$ to end the

\footnotetext{
${ }^{64}$ Three binding opinions were issued in 2008, two relating to Flersheim heirs and another one on the Goudstikker collection. Binding Advice Concerning the dispute over the Restitution of the Painting A Prayer before Supper by Jan Toorop from the estate of E. Flersheim, currently in the possession of the Zeeuwse Museum Foundation, RC 3.45, 7 April 2008; Binding Advice Concerning the Dispute over the Restitution of the Painting Thames at London by Jan Toorop from the Estate of E. Flersheim, Currently in the possession of Rotterdam Municipal Council, RC 3.48, 3 March 2008. These binding opinions were well received in the Netherlands. See Advisory Committee on the Assessment of Restitution Applications for Items of Cultural Value and the Second World War 2008, 82n59. For the Goudstikker opinion, see Binding Advice Concerning the Dispute over The Marriage of Tobias and Sarah by Jan Steen, RC 3.93, 8 October 2008.

${ }^{65}$ Recommendation regarding Semmel, RC 1.75, 1 July 2009, para. 9.

${ }^{66}$ Binding Advice Concerning Christ and the Samaritan Woman at the Well by B. Strozzi, RC 3.128, 25 April 2015 (Semmel/De Fundatie), object owned by the Foundation Hannema de Steurs (Museum "de Fundatie"); Binding Advice Concerning Madonna and Child with Wild Roses by Jan van Scorel, RC 3.131, 25 April 2015 (Semmel/Centraal Museum), object owned by the municipality of Utrecht; Binding Advice Concerning the Landing Stage by M.F. van der Hulst, RC 3.126, 25 April 2015, object owned by Stichting Kunstbezit en Oudheden Groninger Museum (Groninger Museum); Binding Advice Concerning Stag Hunt in the Dunes by Gerrit Claesz Bleker, RC 3.127, 25 April 2015, object owned by the municipality of Haarlem.

${ }^{67}$ Semmel/De Fundatie and Semmel/Centraal Museum; Oost 2018, 163.

${ }^{68}$ Catherine Hickley, "Heirs Outraged as Dutch Panel Rejects Nazi-Era Art Claim," Bloomberg, 8 May 2013, http:// www.bloomberg.com/news/2013-05-08/heirs-outraged-as-dutch-panel-rejectsnazi-era-art-claim.html (accessed 15 March 2021).

${ }^{69}$ The heirs tried their luck in court based on 7:904 of the Dutch Civil Code, which in the end did not bring them any further. Although the binding opinion in Semmel/Centraal Museum was quashed by the judge on fundamental procedural errors, the judge could only refer the heirs back to the RC. From a strictly legal perspective, the ownership rights of the municipality were unassailable and, thus, a further legal procedure would be without avail. For the judgment of the municipal district court of Midden-Nederland, see Plaintiffs v. Municipality of Utrecht, ECLI:NL:RBMNE:2014:6833 (District Court Midden Nederland, 10 December 2014). On the further course of events and the heirs' doubts about the RC's impartiality, see Oost 2018, 169-71.

${ }^{70}$ Like the liberalized government policy set forth from 2001, this change was based on advice sought by the government. An ad hoc advisory committee of the Council of Culture was specifically assigned this task and
} 
coexistence of two separate assessment frameworks and the differing treatment of objects merely depending on their location. ${ }^{71}$ As of 19 July 2012, the objects in the Dutch National Art Collection that were not designated as part of the NK Collection were to be assessed on the basis of the principles of reasonableness and fairness. Whereas, in 2001, the wish for a generous policy led the government to decide to expand the range of eligible objects from only the NK Collection to the entire Dutch collection, this decision was now reversed to account for the differences in the provenance of the objects. The state secretary stressed that, unlike the NK Collection, other objects in the Dutch National Art Collection had been acquired via "normal channels" such as auctions and bought in good faith. ${ }^{72}$ The liberalized government guidelines were now considered less suitable for dealing with claims concerning these objects, as they left no room to consider the differences in the provenance of these objects nor any flexibility in terms of the available remedies.

The second tranche of unification was set for 30 June 2015, which meant that the NK Collection was also to be dealt with on the basis of the principles of reasonableness and fairness. Here, the motivation given was that the liberalized policy did not "need to be drawn out indefinitely," thus implying that a conclusion of involuntary loss due to the Nazi regime would not necessarily lead to a recommendation for restitution. ${ }^{73}$ That said, the state secretary generally emphasized at the same time that a weighing of interests was less suitable when the current possessor could have or should have known about the "tainted" provenance of the claimed object. It was however left to the discretion of the RC to deal with this in individual claims. ${ }^{74}$

On a final note, it should be mentioned that the necessity of these considerable changes originated in certain assumptions that had currency around the time of the establishment of the RC. As time passed, those assumptions proved to be wrong. For one thing, it was thought that the liberalized restitution policy was only a temporary measure. The expectation was that the RC would remain in function for about three to five years; it was estimated that it would deal with perhaps 30 , but no more than 50 , cases. ${ }^{75}$ The choice for a flexible, lowthreshold procedure guided by open norms tallied well with this expectation, given the claimants' perspective. In 2012, when the unification of the restitution policy was announced, 10 years after the establishment of the RC, it became clear that discussion of

consisted of the same members as the Ekkart Committee that advised the Dutch government between 1997 and 2005. For the advice (only in Dutch), see Raad voor Cultuur, Appendix (bgl-174352), 25 January 2012, Kamerstukken II (Parliamentary Papers), 2011-12, 25839, no. 41. For a summary in English, see Advisory Committee on the Assessment of Restitution Applications for Items of Cultural Value and the Second World War 2012, 12-16.

${ }^{71}$ In this regard, see the motivation relating to the wish to avoid "possible confusion" for claimants. See Letter from the State Secretary of OCW to the Lower House with His Response to the Advice of the Council for Culture about the Restitution Policy in Regard to Items of Cultural Value, 22 June 2012, Kamerstukken II (Parliamentary Papers), 2011-12, 25839, no. 41, 5 (Letter from the State Secretary 2012).

72 Letter from the State Secretary 2012, 2-3; Oost 2018, 150.

${ }^{73}$ Quotation from the Council of Culture's advice on the basis of which the state secretary decided to act accordingly. Letter from the State Secretary 2012, 5.

${ }^{74}$ Letter from the State Secretary 2012, 5-6; see also Establishing Decree 2001, which was amended in 2012 to include Art. 2, sub. 6, where it is explicitly expressed that, as of 2012, the "committee attaches great importance to the circumstances of the acquisition by the possessor and the possibility of knowledge of the suspicious origin at the time of the acquisition of the cultural object in question." In 2015, the chair of the RC stated that the Ekkart Recommendations were by all means not stored in the archives, indicating that these recommendations still play an important role in the RC's decisions. Foreword by the Chairman Willibrord Davids, Advisory Committee on the Assessment of Restitution Applications for Items of Cultural Value and the Second World War 2015, 5-6; Oost 2018, 152-53.

${ }^{75}$ This number is mentioned in several official documents, including, for example, Establishing Decree 2001, explanatory notes; Kamerstukken II (Parliamentary Papers), 2001-2, 25839, no. 28, 7. 
a possible end term for the policy had been given up on. ${ }^{76}$ In the meantime, the flexible nature of the policy allowed a constantly changing set of rules to be applied, which, as the Semmel case showed, marked the Dutch policy, as such, with "blind spots" and, accordingly, with confusion..$^{77}$ Besides, the "increased legalization" of claims, which meant the increased involvement of lawyers working on a no-cure-no-pay basis, only added to the confusion. Restitution has remained the sole focus of the procedures at the RC despite the flexibility in terms of remedies and a possibly anticipated mediatory role, which was an important rationale for the changes in $2012 .{ }^{78}$ The procedure is increasingly thought to be litigious and has been criticized for lacking in traditional legal guarantees such as independence and impartiality. ${ }^{79}$ The previous discussion of the origins of the RC has shown, however, that the procedure at the RC was explicitly not intended to provide a venue comparable to traditional legal adjudication.

Also, whereas in 2001 it was assumed that the RC's second task was to issue opinions relevant to disputes between traditional private parties, of the 20 binding opinions, ${ }^{80}$ only one concerned a dispute between two private individuals. ${ }^{81}$ The RC's duty to issue binding opinions has mainly been exercised vis-à-vis museums (legally organized as foundations, which are entities governed by private law), ${ }^{82}$ municipalities, and provinces whenever the

\footnotetext{
${ }^{76}$ Letter from the State Secretary 2012, 5; By the time this article is published, the RC has been active for almost 20 years and has issued well over 160 recommendations and opinions.

77 One of the conclusions of Bureau Berenschot, a Dutch management consulting firm, which conducted a review on the functioning of the Dutch RC at the request of the minister in 2015. Oost 2018, 164; Bureau Berenschot, "Een toekomstgericht restitutiebeleid: Over een duurzame, transparante en onomstreden organisatie rondom restituties," 2015, https://www.rijksoverheid.nl/documenten/rapporten/2015/05/01/een-toekomstgericht-resti tutiebeleid (accessed 15 March 2021).

78 On the "legalization" of claims, see Letter from the Minister of Education Culture and Science to Parliament, 4 October 2016, Kamerstukken II (Parliamentary Papers), 2016-17, 25839, no. 42. The Kohnstamm Committee recently urged the RC to take a more active approach towards mediatory solutions, especially relating to objects acquired in good faith. Kohnstamm Committee 2020, 29-30.

${ }^{79}$ Demonstrated by correspondence between the Semmel heirs' lawyer and the minister after the court proceedings. The fact that the Dutch RC approached the municipality for a transcript of the judgment of the municipal court was argued to be "inconsistent," considering the RC's "judicial function" and a display of bias by the RC. Letter to the Minister of Education Culture and Science from the Legal Representatives of the Semmel Heirs, 16 January 2015 (on file with the author); see also Oost 2018, 170-71. Similar arguments have been advanced by the representatives of the Lewenstein heirs. See "Erven beschuldigen de Restitutiecommissie van 'partijdigheid' bij teruggave oorlogskunst," NRC, 14 January 2020.

${ }^{80}$ For the latest overview of opinions, see Advisory Committee on the Assessment of Restitution Applications for Items of Cultural Value and the Second World War 2019, 20.

${ }^{81}$ The dispute was about the possible division of the sales proceeds of the painting Road to Calvary and did not concern a request for restitution. Both parties agreed that the painting was involuntarily lost due to the Nazi regime, given that it was part of the trading stock of the art dealership Margraf, which was owned by Jakob and Rosa Oppenheimer, who were targeted by the Nazis from the start of the Nazi reign. The RC held that the owner's share should be twice that of the Oppenheimer family, as the current owner's right of ownership carried the most weight for the committee, taking into account that the painting was bought in good faith at a jumble sale. As it was clear that the Road to Calvary was a looted work of art, the RC held that this brought forth a moral obligation toward the Oppenheimer family. See Binding Advice Concerning the Dispute over the Painting Road to Calvary, RC 3.95, 3 May 2010. It is noted here that the UK's SAP took a different view on the circumstances of the Oppenheimer heirs' loss. Report of the Spoliation Advisory Panel in Respect of an Oil Painting by Pierre-Auguste Renoir, "The coast at cagnes," Now in the Possession of Bristol City Council, HC 440, 16 September 2015 (Bristol CC/Margraf Claim).

${ }^{82}$ On the various types of museums in the Netherlands, ranging from private museums to municipal and provincial museums see, "In samenpraak: Suggesties voor het contact tussen musea en gemeenten," 2015, 11-15 (only in Dutch), https://www.museumvereniging.nl/media/publicationpage/publicationFile/_mv_samenspraak_ def.pdf (accessed 15 March 2021). This categorization relates to the provenance of the collection of the museums as well as the legal question of ownership.
} 
public interest has been asserted and factored into the RC's considerations. ${ }^{83}$ The substantive difference in assessment frameworks between objects that all have a public connotation has proven hard to explain, as illustrated by the Semmel case. The fact that, due to the unification of the restitution policy, the Regulations for Opinion Procedure now has the upper hand in dealing with claims, only adds grist to the mill and confusion for claimants. In addition, since the RC itself drafted these Regulations, the democratic legitimacy of the document can rather easily be argued as being weak. ${ }^{84}$

Given this preponderance accorded to the public interest, one last development needs to be mentioned here, and it only adds to the confusion about the Dutch restitution policy. In 2016, the new Dutch Heritage Act came into force, which contains a protective system meant to preserve Dutch cultural heritage. ${ }^{85}$ When the disposal of an object held in a public collection is being considered, a recommendation from the Protection Worthiness Assessment Committee (Toetsingscommissie Beschermwaardigheid, or TCB) must be sought to assess the indispensability and irreplaceability of the object. ${ }^{86}$ It seems that this law does not need to be a liability for the effectuation of a positive recommendation on restitution, due to the non-legally binding status of the recommendation and the discretionary power of the public actors involved. During the parliamentary debate on the Heritage Act, the minister indicated that a recommendation from the RC would constitute a guiding principle in the assertion of the discretionary power.$^{87}$ However, the omission of the legislator in this regard caused haziness on the possible implications for the Dutch restitution policy. It would have been more clear-cut if the legislator had at least included the RC's recommendations and opinions in that legal framework. ${ }^{88}$

\footnotetext{
${ }^{83}$ Provenance research conducted under the auspices of the Netherlands Museums Association, again led by Rudi Ekkart, had an important bearing in this regard. For more information, see Museale Verwervingen, "About the Investigation," http://www.musealeverwervingen.nl/en/36/about-theinvestigation/ (accessed 15 March 2021).

${ }^{84}$ Establishing Decree, Art. 4, sub. 2. The minister did accept these Regulations as "a basic principle." Advisory Committee on the Assessment of Restitution Applications for Items of Cultural Value and the Second World War 2008, 5. In contrast, the first task of the RC was subject to poignant discussions in Parliament between 1997 and 2001.

${ }^{85}$ The Heritage Act harmonized various acts and separate sets of regulations regarding the protection and preservation of Dutch cultural heritage. See Cultural Heritage Agency, "1.2 Reasons for a single Heritage Act," 41, https://cultureelerfgoed.nl/sites/default/files/publications/heritage-act-2016.pdf (accessed 15 March 2021).

${ }^{86}$ See Heritage Act, Arts. 4.19, 4.20, on the scope of the TCBs advice and rules on the composition as well as safeguards for its independence.

87 "Ik hecht eraan dat in voorkomende gevallen kunst nog steeds teruggegeven wordt waar die in verkeerde handen is gekomen." Answer of Minister Jet Bussemaker on MP Van Veen's Question on the Relation between the RC's Mandate and the Heritage Act, Handelingen TK (Parliamentary Proceedings Second Chamber), 2014-15, no. 90, 21, 90-20-37; Oost, 2018, 153. In 2019 the RC dealt with this issue in a claim submitted after July 2015 concerning two NK-objects. The TCB deemed the works worthy of protection within the meaning of the Heritage Act. The minister consequently requested the RC to take this into account. The RC however stated not to have a task in the Dutch Heritage Act and noted that although it may take this into account on the basis of principles of reasonableness and fairness, there was no reason to do so in this case as the involuntariness of loss was sufficiently plausible. Recommendation regarding Lierens, RC 1.69, 16 April 2019, para. 22 (Lierens Recommendation).

${ }^{88}$ The Kohnstamm Committee referred, albeit implicitly, to the legislator's role in view of the RC's task. Kohnstamm Committee 2020, 29. In the first intermediate report of the so-called Commissie Collectie Nederland, established in view of the minister's wish to increase the protection of public and private cultural objects vital ("belangwekkend") to the Dutch Cultural Heritage, the Commissie's views on the possible contours of the protection of (movable) cultural objects and applicable criteria for protection were presented. According to the Commissie Collectie Nederland, objects involuntary lost during World War II and colonialism should be excluded from that protection. See Letter from the Minister of Education Culture and Science, Kamerstukken II (Parliamentary Papers) 2020-21 32820, no. 409, 14. It is expected that the Heritage Act will be amended in line with the recommendations of Commissie Collectie Nederland. See Letter from the Minister of Education Culture and Science, 17 December 2019, Kamerstukken II (Parliamentary Papers), 2019-20, 32820, no. 332.
} 
Current critique of the Dutch restitution policy cannot be seen as being separate from the almost constantly changing rules. Zeroing in on the weighing of interests could open up a Pandora's box for claimants, although perhaps not intentionally. Public interest works like a boomerang when it outweighs the interests of the claimant, especially when the involuntariness of the loss, in all likelihood, was caused by the Nazi regime. The 2018 Lewenstein/ Kandinsky case and the subsequent international commotion serve as an illustration, even though the 2012 unification was meant to provide clarity. ${ }^{89}$

\section{The 2018 Lewenstein/Amsterdam City Council claim}

As mentioned in the Introduction, the Lewenstein/Kandinsky case involved a restitution claim by the Lewenstein-Klein heirs concerning a Kandinsky entitled Painting with Houses, owned by the Amsterdam municipality and on display at the Amsterdam Stedelijk Museum. It should be stressed here that the case concerning the Kandinsky is illustrative of the multiple difficulties that committees such as the RC have to deal with, as it was marked by highly fragmentary evidence..$^{90}$ This made both the decision on ownership by the former owner as well as the involuntariness of loss not an easy one to tackle. That said, how the weighing of interests takes place and its result seem to have at least in part provoked the still ongoing international critique. ${ }^{91}$

Initially, the Kandinsky belonged to Emanuel Lewenstein and his wife Hedwig. Their two children Robert and Wilhelmina Lewenstein were their legal heirs. Robert, who took over the family business Lewenstein NV, married Irma Klein in 1933, four years before the death of their last surviving parent, Hedwig, in 1937. The marriage of Robert and Irma did not last. Robert left Irma "around mid-August 1938" and left for France in 1939 with his new partner. Robert and Irma were granted a legal separation on 27 June 1940, but the actual division of their matrimonial estate was set seven years later by a notarial deed dated 7 June 1947. With respect to the matter of ownership, the heirs of the three possible former owners, Wilhelmina, Robert, and Robert's ex-wife Irma Klein, were the claimants in this case. ${ }^{92}$ Based on the last will of the mother Hedwig, the RC deemed it highly likely that the object had been assigned to Robert and was accordingly included in the property of Irma and Robert, as they were married in a community of property. ${ }^{93}$ Although the

\footnotetext{
${ }^{89}$ Oost, 2018, 152-53.

${ }^{90}$ See also Charlotte Woodhead, Implementing Recommendation 3 of the 2017 London Conference Action Plan, March 2019 (revised October 2019), 108, https://assets.publishing.service.gov.uk/government/uploads/system/uploads/ attachment_data/file/862067/Woodhead_Recommendation_3_FINAL_report_October_2019.pdf (accessed 15 March 2021).

${ }^{91}$ The heirs could not agree on the ownership of the work at the time of the auction but agreed that they would "allocate the proceeds arising from restitution" irrespective of the RC's conclusion of ownership. The RC, however, rejected the heirs' stance: a decision on ownership was not only necessary to determine the eligible party for restitution but also for the assessment of the case as a whole. Lewenstein/Amsterdam City Council Claim, paras 4.1, 6.3.1, 6.6.

${ }^{92}$ Lewenstein/Amsterdam City Council Claim, para. 6.3.1.

${ }^{93}$ And thus not assigned to Wilhemina Lewenstein. The RC considered that, although the 1937 testament suggested that the family's art collection was to be divided by drawing lots, a 1938 deed was in the end decisive. Based on the 1938 deed, the RC found it most plausible that the painting as part of the "remaining assets" was assigned to Robert Lewenstein to compensate for the debts Wilhelmina owed to her late mother. The RC therewith disregarded a 1948 letter from Robert and Wilhelmina's aunt Betty Lewenstein that could suggest joint ownership of the works by Robert and Wilhemina. This letter concerned an inquiry on the whereabouts of another Kandinsky, The Colorful Life, which the Lewenstein family in 1933 loaned to the Stedelijk Museum. Betty Lewenstein made the inquiries on behalf of her niece, Wilhemina Lewenstein, as the painting was once owned by her brother Emanual. According to Betty, it now belonged to his two legal heirs, her niece Wilhemina being one of those heirs. Although the Dutch RC found this letter "less easy to explain," it was underlined that this letter concerned a different
} 
Kandinsky was not explicitly mentioned in the 1947 deed that divided their possessions, the committee was of the opinion that the Kandinsky should be assigned to Irma Klein. The $\mathrm{RC}$ referred to the deed, which stated that the matrimonial belongings had already been divided up to the satisfaction of both parties and that there was no need for a retrospective settlement. ${ }^{94}$

The heirs' discontent and the consequent international commotion originated in the following remark in the binding opinion of the RC, which relates to the RC's assessment of the nature of the loss by Irma Klein:

[T] he sale of the painting cannot be considered in isolation from the Nazi regime, but it was also in part the consequence of deteriorating financial circumstances in which Robert Lewenstein and Irma Klein found themselves well before the German invasion. In the Committee's view, this provides a less powerful basis for restitution than a case in which there was theft or confiscation. ${ }^{95}$

The fact that two separate assessment frameworks remained was once again relevant, as it had been in the case of the Semmel heirs, and there was confusion about which of those rules should prevail in this case. Based on the relaxed governmental guidelines, a sale in the Netherlands after 10 May 1940 by a private Jewish individual was considered involuntary unless there were factors that expressly proved otherwise. Many of the circumstances of the sale by Irma Klein, how the sale occurred, and what happened to the sales proceeds remained unclear, whereas the sale occurred after 10 May 1940. And, thus, from the claimants' perspective, this was a clear-cut case: the loss occurred after 10 May 1940; therefore, the reversal of proof should apply, and restitution should be awarded.

The RC nevertheless stressed that these government guidelines are not "directly applicable to binding opinion cases." 96 The "determining factor" in this case was therefore a weighing of interests. ${ }^{97}$ Although not ruling out an involuntary loss, the RC pointed out several factors suggesting that Robert Lewenstein and Irma Klein were having personal financial difficulties and that the sale was therefore most likely voluntary. ${ }^{98}$ Not only did these circumstances of loss provide a "less powerful basis for restitution," but there were also no indications that Irma Klein undertook efforts to reclaim the work after World War II. There was furthermore no evidence to suggest that the painting was acquired in bad faith. In addition, the Lewenstein family had loaned objects to the Stedelijk Museum on various occasions between 1933 and 1960, indicating a good relationship between the parties. Therefore, as the Kandinsky held a significant position in the Stedelijk Museum's collection, this outweighed the interests of Irma Klein's heir, who, apart from being the rightful heir, had "no past emotional interest or emotional bond" to the claimed object. ${ }^{99}$

Kandinsky and could, as a single dissonant, not set aside the multiple indications that ownership was assigned to Robert Lewenstein alone. Lewenstein/Amsterdam City Council Claim, paras. 3.12, 6.3.2.

${ }^{94}$ Several documents furthermore suggested that Irma Klein had actual possession over the work at the time of its sale and that she sold the painting on her own account. See Lewenstein/Amsterdam City Council Claim, paras. 6.3.3, 6.4.1.

${ }_{95}$ Lewenstein/Amsterdam City Council Claim, para. 6.8.

${ }^{96}$ Lewenstein/Amsterdam City Council Claim, para. 6.5.

${ }^{97}$ Lewenstein/Amsterdam City Council Claim, para. 6.5.3.

${ }^{98}$ In part due to substantial losses incurred by the Lewenstein NV in the period between 1935 and 1938.

${ }^{99}$ As mentioned, the Lewenstein/Kansinsky claim will most likely be reassessed. Letter of the Board of Mayor and Alderman 2021; Letter from the Minister to the Lower House 2021, 6. It remains to be seen whether a more mediatory approach in a possible second assessment by the RC, as advocated by the Kohnstamm Committee would be appreciated by the heirs, who up until now aimed for the return of the Kandinsky rather than something else. Kohnstamm Committee 2020, 29-30. 


\section{The "public interest" from a comparative perspective}

Both the Dutch government and the RC have repeatedly reiterated the stance that the choices made regarding the task in the binding opinion procedure are in keeping with the 1999 Washington Principles, ${ }^{100}$ which, given the actual content of those Principles, are not necessarily wrong. Principles IV, VIII, IX, and X call for a "just and fair solution." Nations are encouraged to establish "alternative dispute resolution mechanisms" to resolve ownership issues while considering the "unavoidable gaps and ambiguities in the provenance" of these objects due to the passage of time as well as the atrocities committed during the Holocaust. The Principles do not stipulate by any means how this just and fair solution should be achieved. ${ }^{101}$ Moreover, they recognize that a just and fair solution "may vary according to the facts and circumstances surrounding a case."102

\section{The Dutch assessment framework: A note of discord?}

A quick peek across Dutch borders shows that a differing array of choices have been made in this regard, whereas the Netherlands seems to be at the outer end of the spectrum in both its explicit inclusion of the public interest in the applicable framework as well as the RC's caseload. ${ }^{103}$ The system provided for by Austria's Kunstrückgabegesetz (Art Restitution Act) resides at the exact opposite end of this spectrum. ${ }^{104}$ The Kunstrückgabebeirat (Beirat) is called to identify former owners and advise the responsible minister in this regard. The Kunstrückgabegesetz designates three categories of objects eligible for restitution provided certain conditions enumerated therein are fulfilled. ${ }^{105}$ The public interest is not one of these conditions. ${ }^{106}$ Article 4 of the Kunstrückgabegesetz furthermore provides an exemption

${ }^{100}$ For example, see Letter of the State Secretary 2012, 4; Lewenstein/Amsterdam City Council Claim, para. 5.3

${ }^{101}$ Weller 2015, 201-12; Campfens 2017, 315-47; Oost 2018.

102 Oost 2012, 15-16; Weller 2015, 201-12; Campfens 2017, 315-47.

${ }^{103}$ Although this article focuses on the public interest as part of the substantive assessment frameworks on the basis of which Nazi-spoliated art claims are considered, possible barriers for restitution resulting from regimes protecting the national cultural heritage are also shortly discussed in this section, as they may affect the claimant's position in terms of their choice in remedies.

${ }^{104}$ Bundesgesetz über die Rückgabe von Kunstgegenständen und sonstigem beweglichem Kulturgut aus den österreichischen Bundesmuseen und Sammlungen und aus dem sonstigen Bundeseigentum, BGBl, I, no. 181/1998 (Kunstrückgabegesetz 1998), as amended by BGBl, I no. 117/2009, para. 1 (Kunstrückgabegesetz 2009). For an English translation of the Act, see Rechtsinformationssystem des Bundes, https:/www.ris.bka.gv.at/Dokumente/Erv/ ERV_1998_1_181/ERV_1998_1_181.pdf (accessed 15 March 2021).

${ }^{105}$ Important in the Austrian assessment is whether the object involved was subject of a legal transaction that is null and void pursuant to $\S 1$ of the Bundesgesetzes über die Nichtigerklärung von Rechtsgeschäften und sonstigen Rechtshandlungen, die während der deutschen Besetzung Österreichs erfolgt sind, BGBl. Nr. 106/1946, which primarily relates to the category of objects identified in § 1 (2), (2a) of the Kunstrückgabegesetz. The bulk of cases dealt with by the Kunstrückgabebeirat concerns this category of objects. See Blimlinger and Jabloner, 2009, for a general discussion; see, Dewey, 2020 for a specific example of the Kunstrückgabebeirat's application of §1 (2).

${ }^{106}$ Within Austrian borders, much of the discussion on Austria's "tainted" past regarding Nazi-looted cultural objects has focused on the so-called practice of obligatory "Widmungen" ("dedications" or "gifts") in exchange for an export license in the immediate post-World War II years, which was based on the Bundesgesetz betreffend den Schutz von Denkmalen wegen ihrer geschichtlichen, künstlerischen oder sonstigen kulturellen Bedeutung, BGBl. Nr. 533/1923 (Denkmalschutzgesetz). The fact that restitution was effectively barred as a consequence of the legal framework that protected the Austrian cultural heritage led to a critical discussion on the question whether these families after World War II were "erneut bestohlen" or "robbed again" but, this time, by the Austrian state. The Kunstrückgabegesetz by way of the category of objects identified in $§ 1$ (1), specifically aims to correct this practice. On the "Widmungen" practice, see Reinhard Binder-Krieglstein, "Restitution und Entschädigung in Vergangenheit und Gegenwart aus juristischer Sicht," 2002, http://david.juden.at/kulturzeitschrift/50-54/Main\%20frame_Arti kel52_Krieglstein.htm (accessed 15 March 2021). For an infamous case in this regard, see Trenkler 1999. 
from the export ban in the Denkmalschutzgesetz (Cultural Heritage Act) 1923, the Austrian instrument for the protection of national cultural heritage. ${ }^{107}$ Whenever the conditions of the Kunstrückgabegesetz are met and objects are transferred to their owners or their heirs based on a recommendation of the Beirat, the export ban is inapplicable for 25 years after the actual transfer of the object. ${ }^{108}$

For the French Commission pour l'indemnisation des victimes de spoliations (CIVS), the primary question is whether a loss was caused by anti-Semitic legislation and had occurred on French soil. ${ }^{109}$ As in the Austrian situation, the public interest does not appear to play any role in the recommendations of the CIVS. That said, the public interest - via the French legal system for the protection of the national cultural heritage - has been seen to bring about potential legal difficulties when a restitution claim depends on the categorization of the object at hand. ${ }^{110}$ In France, the Musées Nationaux Récuperation (MNR) Collection ${ }^{111}$ is entirely composed of artworks recuperated after World War II. ${ }^{112}$ It is governed by a different regime than non-MNR works. The MNR Collection enjoys a special status within the French public collections, as the French state never became its owner ${ }^{113}$ and acts as a mere guardian or "detenteur provisoire." ${ }^{114}$ In 2014, the French Conseil d'État confirmed this special status and made it clear that, in keeping with the CIVS mandate, those MNR objects with a Nazi lootingrelated provenance are eligible for restitution, given that France has enacted no law or legal rule on the basis of which prescription could preclude restitution. ${ }^{115}$

\footnotetext{
${ }^{107}$ For the export ban, see Art. 16 of the Denkmalschutzgesetz, https://www.ris.bka.gv.at/GeltendeFassung.wx? Abfrage=Bundesnormen\&Gesetzesnummer $=10009184$.

${ }^{108}$ The Kunstrückgabegesetz uses the word "übereignen," which in the unofficial translation of the Austrian federal government is translated as "transfer." The verb "restitute" is not used, which relates to the system of the Act that does not create a legal right to claim. The Kunstrückgabegesetz is a species of a so-called Selbstbindungsgesetz based on Article 17 of the Bundesverfassungsgesetz. The Act effectively results in a mere possibility for the Austrian government to decide on a certain matter - "ein ermächtigendes Gesetz." In this regard, see Kahl $2018,12$. The inward-looking Austrian restitution process has been criticized, see Noll 2011 and specifically in the wake of the Beirat's decision on the Erich Lederer case concerning the Beethoven Frieze, see "Austria Refuses to Link Nazilinked Frieze," Independent Online, 6 March 2015, https://www.iol.co.za/news/world/austria-refuses-to-returnnazi-linked-frieze-1828452 (accessed 15 March 2021). For the recommendation, see Empfehlung des Beirates, Lederer Erich, 6 March 2015.

109 See generally the Decree Establishing the CIVS, Décret n 99-778, 10 September 1999, Art. 1. This decree has been updated and changed multiple times. For an overview, see "Les textes réglementaires," République française, n. d., http://www.civs.gouv.fr/fr/la-civs/les-textes-reglementaires/ (accessed 15 March 2021). For more information on possibly relevant criteria or facts, see "Ses competences," n.d., http://www.civs.gouv.fr/fr/la-civs/ses-compe tences/ (accessed 15 March 2021). Oost 2012, 148; Marck and Muller 2015, 60-61.

110 Zivie 2018, 49.

${ }^{111}$ Following the idea of the French national museums (musées nationaux) some 2,000 artworks were selected out of 16,000 works via a so-called "commission de choix" based on their added value to the French national cultural heritage. Le Masne de Chermont and Schulmann 2000, 36; Le Masne de Chermont and Sigal-Klagsblad 2008, 29; Oost 2012, 142; Marck and Muller 2015, 57.

112 And, as in the Dutch situation, could not, or were not, returned in the immediate post-World War II years.

${ }^{113}$ As stipulated in a Decree issued in 1949, Décret no. 49-1344, 30 September 1949, http://www2.culture. gouv.fr/documentation/mnr/MnR-tj.htm (accessed 15 March 2021). Although Art. 5 of this decree foresaw an end term in the possibility of claims of these works by mentioning "jusqu'à l'expiration du délai legal de revendication," such a term was never set. Zivie 2018, 17.

${ }^{114}$ For the French term, see "MNR: Musée Nationaux Récupération," Ministère de la culture, n.d., https:// www.culture.gouv.fr/Espace-documentation/Bases-de-donnees-Culture/MNR-Musee-Nationaux-Recuperation (accessed 15 March 2021).

${ }^{115}$ In the same decision, the Conseil d'État, however, confirmed the validity of the decision of the French Ministry of Foreign Affairs to reject a restitution request concerning the three Musées Nationaux Récuperation (MNR) works. The request was made by the heirs of the Austrian national who lost possession of the work at the end of World War II after seizure by the American forces due to their suspicion that earlier in the war these objects were
} 
This special status of the MNR Collection, resulting in objects being eligible for restitution if a Nazi-looting background can be established, does not apply to objects that ended up in French public collections through acquisition, gifts, or bequests. The strict French legal regime protecting cultural heritage through the principle of the inalienability of public collections applies to such objects, thus posing a legal barrier for restitution. ${ }^{116}$ In a 2018 report drawn up on behalf of the French Ministry of Culture, it was pointed out that pragmatic solutions are sought when these inalienable objects prove to have a tainted provenance. Sometimes an administrative adjustment is possible - that is, changing the entry of an object to "inscription indue" (improper registration), thus allowing the work to be released. ${ }^{117}$ In other cases, monetary compensation has been the solution, while the disputed object remains in the museum. ${ }^{118}$ As a final note on the French situation, a renewed effort for restitution was launched in 2018; it aims for the restitution of objects that were spoliated during the German occupation of France and objects spoliated between 1933 and 1945 that are now located on French territory. ${ }^{119}$ To this end, a so-called Mission de recherche et de restitution des biens culturels spoliés entre 1933 et 1945 was established within the Ministry of Culture to facilitate provenance research not only into the MNR Collection but also into the French public collections. The mandate of the CIVS was also changed. It now explicitly refers to the possibility for the CIVS to make recommendations regarding Nazi-spoliated cultural objects, "particularly" relating to those objects in the MNR Collection, either amounting to restitution or financial compensation. ${ }^{120}$ The "ad hoc" provision - recommended in the 2018 report and meant to exempt Nazi-spoliated objects in French public collections other than the MNR Collection from the principle of alienability to facilitate the restitution of objects with a Nazi-looting provenance - has not been followed up yet. ${ }^{121}$ It has been said that the CIVS in these cases will most likely resort to a recommendation for financial compensation, irrespective of a claimant's possible preference for restitution as the remedy. ${ }^{122}$

Similar legal hurdles in the sphere of the protection of the national cultural heritage were addressed in Germany in 2016 when the Kulturgutschutzgesetz (Cultural Property

subjected to Nazi spoliation. The works were added to the MNR Collection after the Americans handed the works over to the French authorities. See Conseil d'État, "Mmes D ... et B," Doc. 349789, 30 July 2014.

${ }^{116}$ Which is based on the legal system provided by the Code du patrimoine (Heritage Code) and the Code général de la propriété des personnes publiques (General Code of the Property of Public Personnel [CGPPP]). For French public museums, the inalienability is based on Articles L451-5 of the Heritage Code and Article L3111-1 of the CGPPP, which in short can only be surmounted by the enactment of a specific Act of Parliament On the specific legal difficulties regarding non-MNR work, see Zivie 2018, 47, 48.

117 This possibility, however, is limited to objects that cannot be linked to an acquisition process or a gift or bequest as in those cases an "improper entry" is hard to maintain. Zivie 2018, 48.

118 Zivie 2018, 18n17.

${ }^{119}$ See the leaflet "La nouvelle organisation française pour la restitution des biens culturels spoliés du fait de national-socialisme," reprinted in “Actualités," République française, 17 May 2019, http://www.civs.gouv.fr/images/ pdf/documents_utiles/autres_documents/FR-FLYER-2019-v3-PageApage.pdf (accessed 15 March 2021).

${ }^{120}$ Décret no. 2018-829, 1 October 2018, Art. 1-1, http://www.civs.gouv.fr/images/pdf/lacivs/docjoints/decret2018-829-du-1er-octobre-2018.pdf (accessed 15 March 2021).

${ }^{121}$ As confirmed by David Zivie by email, 24 August 2020 (on file with the author).

122 Zivie 2018, 49. Interestingly, the French minister of Culture recently announced, on 15 March 2021, the restitution of a Klimt painting, Roses under the Trees, to the heirs of Nora Stiasny; a decision arising from the French renewed restitution efforts. The work was acquired by the French state in 1980 for the Musée d'Orsay, where the work is on display and thus not an MNR object. The required, separate act has been announced to enable restitution, in light of the Heritage Code and the principle of inalienability. For the announcement, see "Discours," Ministère de la culture, 15 March 2021, https://www.culture.gouv.fr/Presse/Discours/Discours-de-Roselyne-Bache lot-Narquin-ministre-de-la-Culture-prononce-a-1-occasion-de-la-restitution-de-Rosiers-sous-les-arbres-de-Gus tav-Klimt-1 (accessed 15 March 2021). 
Protection Act) came into force. ${ }^{123}$ And yet it appears that the German Beratende Kommission $^{124}$ in a recent recommendation moved toward the Dutch RC's assessment framework and practice. ${ }^{125}$ In recent years, due to ongoing criticism relating to, among other things, a lack of substantive reasoning and motivation in the Beratende Kommission's recommendations, ${ }^{126}$ action has been taken to clarify and improve the procedure as well the substantive factors in dealing with restitution claims. ${ }^{127}$ This led, in 2016, to the promulgation of the Verfahrensordnung (Rules of Procedure) by the Beratende Kommission $^{128}$ as well as a revision by the German federal government's commissioner for culture and the media, in 2019, of the Handreichung (Guidelines) on provenance research and restitution for German public institutions. ${ }^{129}$ Amongst other things, it has been clarified that the Beratende Kommission shall take "particular account of" the circumstances of the loss, the circumstances of acquisition, and the conducted provenance research. ${ }^{130}$ Still, the situation in Germany on the public interest remains somewhat opaque. ${ }^{131}$ The

${ }^{123}$ Gesetz zum Schutz von Kulturgut (Kultursgutschutzgesetz-KGSG), BGBl. I S. 1914, 31 July 2016, lastly modified by article 40 des Gesetzes vom 20. November 2019, BGBl. I S. 1626, Art. 13, ss. 1, 2, http://www.gesetze-iminternet.de/kgsg/index.html (accessed 15 March 2021).

${ }^{124}$ Officially: Beratende Kommission im Zusammenhang mit der Rückgabe NS-verfolgungsbedingt entzogenen Kulturguts, insbesondere aus jüdischem Besitz. The Beratende Kommission is also frequently referred to as the Limbach Kommission after its first chair Jutta Limbach, who passed away in 2016.

${ }^{125}$ In Germany, the Washington Principles were followed up in 1999 with a Common Statement (Gemeinsame Erklärung) from the German Federation, the Länder and the National Associations of Local Authorities to Express Their Commitment to Track Down and Return Nazi-Looted Art. On 5 December 2002, the Common Statement was complemented with the decision to establish the Limbach Kommission. For the (short) document merely announcing the Limbach Kommission, see Campfens 2015, 293-94. This document was followed by the Handreichung zur Umsetzung der 'Erklärung der Bundesregierung, der Länder und der kommunalen Spitzenverbände zur Auffindung und zur Rückgabe NS-verfolgungsbedingt entzogenen Kulturgutes, insbesondere aus jüdischem Besitz' vom Dezember 1999 in 2007, which were revised in 2019.

${ }^{126}$ Catalyzed by recommendations regarding the Welfenschatz in 2014 (Empfehlung der Beratenden Kommission im fall Welfenschatz), the Behrens heirs in 2015 (Empfehlung der Beratenden Kommission in der Sache "Behrens . /. Düsseldorf"), and the Flechtheim heirs in 2016 (Empfehlung der Beratenden Kommission in der Sache Alfred Flechtheim Erben ./. Stiftung Kunstsammlung Nordrhein-Westfalen, Düsseldorf). See "Bisherige Empfehlungen," Beratende-kommission, n.d., https://www.beratende-kommission.de/Webs_BK/DE/Empfehlun gen/Index.html (accessed 15 March 2021). For more references, see Kahmann and Naumann 2015; Kahmann 2016; Weller 2017.

${ }^{127}$ Catherine Hickley, "German Culture Minister Promises to Reform Limbach Commission after Mounting Criticism," The Art Newspaper, 5 August 2016.

128 "Verfahrensordnung der Beratenden Kommission im Zusammenhang mit der Rückgabe NS-verfolgungsbedingt entzogenen Kulturguts, insbesondere aus jüdischem Besitz, vom," 2 November 2016, which were adopted by the Beratende Kommission on 2 November 2016 in consultation with the Federal Government Commissioner for Culture and the Media, the federal states, and national associations of local authorities. See "Verfahrensordnung," Beratende Kommission, n.d., https://www.beratende-kommission.de/Webs_BK/EN/Rules-ofProcedure/Index.html (accessed 15 March 2021) (Verfahrensordnung).

129 “Handreichung zur Umsetzung der 'Erklärung der Bundesregierung, der Länder und der kommunalen Spitzenverbände zur Auffindung und zur Rückgabe NS-verfolgungsbedingt entzogenen Kulturgutes, insbesondere aus jüdischem Besitz' vom Dezember 1999, Neufassung 2019," Beratende Kommission, n.d., https://www.beratendekommission.de/Webs_BK/DE/Grundlagen/Handreichung/Index.html (accessed 15 March 2021) (Handreichung 2019).

${ }^{130}$ Verfahrensordnung, para. 6(4).

${ }^{131}$ Generally, criticism has not faded mainly because the reforms did not alter the fact that both parties involved must mutually agree to bring a case before the Beratende Kommmission. Critically, see Jörg Häntzschel and Catrin Lorch, "Partygeplauder," Süddeutsche Zeitung, 19 February 2019, https://www.sueddeutsche.de/kultur/wer-sollueber-raubkunst-entscheidenpartygeplauder-1.4336493 (accessed 15 March 2021), depicting the Beratende Kommission as a symbol of the sluggish manner that the issue of Nazi-looted art is dealt with in Germany ("LimbachKommission ist zum Symbol für die schleppende und schleichende Aufarbeitung von Raubkunst in Deutschland geworden"). 
Handreichung 2019 states that one of the aspects to consider in deciding on a "just and fair solution" is whether an object has been preserved with considerable effort on the part of the museum over an extended period and has been made accessible to the public. ${ }^{132}$ This formulation leaves room for doubt on its exact rationale; it appears that a conception along the lines of unjust enrichment in terms of the costs made in relation to the object rather than the importance of the object to a museum's collection was meant. ${ }^{133}$ The Beratende Kommission nevertheless referred, in a 2020 recommendation on the dispute between the Carl Hagen heirs and the Bayerischen Staatsgemäldesammlunge, to the (lack of any) significance of the object to the latter museum or, in the wording of the Beratende Kommission, the "curational interest," ${ }^{134}$ in an effort to weigh the interests at hand in favour of the claimants. ${ }^{135}$ Interestingly the Beratende Kommission did arrive at a weighing of interests in spite of the fact that the disputed object - the painting The Lemon Slice (Das Zitronenscheibchen) - was never legally owned by Carl Hagen; rather, it was the subject, along with 20 other paintings, of a security agreement between Hagen's bank and Carl Thüring (the painting's owner and debtor to the bank). ${ }^{136}$ The paintings served as collateral for a loan in 1927, ${ }^{137}$ whereby Hagen's bank was granted ownership rights as a form of security ("Sicherungseigentum") and, thus, the right to sell the objects in case the owner did not fulfill his financial obligations. After Hagen's death in 1938 and in the course of Nazi persecutory measures against his bank and the bank's liquidation, the paintings were indeed sold. Thüring's remaining debt after liquidation was paid in full to the Carl Hagen heirs by $1950 .{ }^{138}$

While acknowledging that, from a legal perspective, Carl Hagen had never obtained full ownership rights to The Lemon Slice, which rendered a full restoration of ownership rights legally impossible, the Beratende Kommission nevertheless recommended restitution on the condition that, if the Hagen heirs were to sell within 10 years, 50 percent of the sales proceeds would have to be reimbursed to the State of Bavaria. The Beratende Kommission emphasized, given its task to provide a just and fair solution, that its assessment was not limited to the legal aspects. Rather, its task, to a great extent, was defined by the inclusion of ethical and moral aspects, upholding the heirs' argument stressing the importance of restitution, as the painting symbolized their suffering and fate during the years of the Nazi reign. ${ }^{139}$ Restitution would thus amount to recognition and compensation of the historical

\footnotetext{
${ }^{132}$ Handreichung 2019, 43.

${ }^{133}$ As confirmed in a response to the author at the Beauftragte der Bundesregierung für Kultur und Medien; email by Aline Woll, 2 October 2020 (on file with the author).

${ }^{134}$ Empfehlung der Beratenden Kommission in der Sache Erben nach A. B. ./. Bayerische Staatsgemäldesammlungen, Beratende Kommission, 1 July 2020, https://www.beratende-kommission.de/Content/06_Kommission/DE/ Empfehlungen/20-07-01-Empfehlung-der-Beratenden-Kommission-im-Fall-B-Bayerische-Staatsgemaeldesamm lungen.pdf?_blob=publicationFile\&v=11 (accessed 15 March 2021) (Carl Hagen Empfehlung).

135 Thereby resolving a long running conflict regarding this painting, which started with an official request for restitution in 2012, which was rejected in 2014 by the Bayerischen Staatsgemäldesammlungen. See, for example, “Alte Pinakothek Rejects Restitution Claim for ‘Das Zitronenscheibchen' by Jacob Ochtervelt,” Codart, 5 August 2014, https://www.codart.nl/museums/alte-pinakothek-rejects-restitution-claim-for-das-zitronenscheibchen-by-jacobochtervelt/ (accessed 15 March 2021).

${ }^{136}$ In this regard, see Handreichung 2019, 35-38, which clearly refers to a loss of ownership of a cultural object for which a claimant has to provide the necessary proof.

137 Amounting to 217.616 Reichsmark.

${ }^{138}$ Carl Hagen Empfehlung.

139 Original quote: “Indes ist die Beratende Kommission in ihrer Suche nach einer 'gerechten und fairen Lösung' gemäß den Washingtoner Prinzipien nicht auf eine juristische Prüfung beschränkt. Vielmehr ist sie ausdrück- lich dazu berufen, darüber hinaus ethisch-moralische Gesichtspunkte heranzuziehen, um zu einer Empfehlung zu gelangen, die auch den Besonderheiten des Einzelfalles Rechnung trägt."
} 
injustice in light of the family's tragic fate, which also caused them to suffer substantial economic losses, including the loss of the family art collection. ${ }^{140}$ On a final note, the Beratende Kommission stated that the Bayerische Staatsgemäldesammlungen had no similar weighty interest capable of opposing the Hagen heirs' interest in restitution; the Bayerische Staatsgemäldesammlungen had received the painting as a mere part of a collection without having any specific curational interest in buying this particular work and that the work had not yet been put on display. Although the Beratende Kommission's policy framework is formulated less clearly than comparable rules in the Netherlands, the Hagen case demonstrates that the public interest is taken into account in the German context. In this particular case the public interest did not carry enough weight to tip the scales in favor of the Bayerische Staatsgemäldesammlungen. On the contrary, it added weight to an otherwise quite weak claim. ${ }^{141}$

Whereas, in Germany, the public interest has recently been introduced in the Beratende Kommission's recommendations, it seems that such a development is unlikely in the United Kingdom (UK). It is interesting in this regard that the SAP, like its counterparts in Germany and the Netherlands, can assess claims on the basis of a weighing of interests. ${ }^{142}$ The SAP's "paramount purpose" is to achieve a just and fair solution for both the claimant and the public institution (museum), ${ }^{143}$ where the emphasis lies on establishing the "moral weight" of a claimant's claim. Moral rather than legal considerations set the tone in proceedings before the SAP. ${ }^{144}$ Although the SAP's recommendations have not been legally binding on the parties involved, ${ }^{145}$ the recommendations do nonetheless have legal bearing since the enactment of the Holocaust Act 2009. ${ }^{146}$ The various statutory regimes governing the UK's public collections contain strict rules on the deaccessioning of objects, which in a few cases

\footnotetext{
${ }^{140}$ Which occurred after the transaction in question. In any case, with this reasoning, the Beratende Kommission gave a rather unprecedented twist to the facts of the case in view of the lack of any legal claim in terms of ownership or compensatory claim. The Kommission disregarded one of the Handreichung's starting points in the assessments of claims: establishing legal ownership, which is the point of departure in all five committees discussed in this paragraph. For contrasting reasoning, see, for example, Report of the Spoliation Advisory Panel in Respect of an Oil Painting by John Constable, Beaching a Boat, Brighton, Now in the Possession of the Tate Gallery, HC 1016, 26 March 2014,43 , where the UK's SAP stated that it was not empowered to make recommendations for "symbolic restitution" on the sole grounds of the suffering of former owners; it is required to evaluate on balance of probability the validity of the claimants original legal title. Spoliation Advisory Panel Constitution and Terms of Reference, para. 15(D) (SAP ToR). See also Recommendation Regarding Wolf, RC 1.101, 9 November 2009, 11, on Daniel Wolf who was the pledge holder but not the owner of the claimed objects. The RC emphasized that its task is to prove legal title to a high degree of probability and that it is not empowered to award restitution as reparation for financial losses. This makes the German situation less comparable to that in the other four countries. That said and however interesting these differences may be, it goes beyond the scope of this article to address this matter further.

${ }^{141}$ Which it did not in the Lewenstein/Amsterdam City Council claim.

${ }^{142}$ Litigation is considered fruitless since original owners are likely to have lost legal title based on the Limitation Act 1939, s. 3(2), as it extinguishes title of the original owner six years after the original conversion, also when conversion was a theft. See generally Palmer 2000, ch. 10; Oost 2012; Woodhead 2013, 168; 2014, 115-16; Marck and Muller 2015, 64.

${ }^{143}$ See SAP ToR, para. 1, referring to objects in the possession of a UK national collection or in another UK museum or gallery established for the public benefit ("the institution"). Though the SAP was primarily established in view of objects residing in public collections, para. 6 of the SAP ToR also allows the SAP to consider claims concerning objects held in a private collection.

${ }^{144}$ SAP ToR, paras. 9, 14, 15(e), 16. It is noted that the moral weight of a claimant's claim carries greater weight since the document's update in July 2016, which now stipulates that the SAP "will only consider whether any particular moral obligation rests on the institution" in case the SAP considers it necessary to arrive at a fair and just solution; on the rationale of the 2016 changes, see Oost 2018, 168n186.

${ }^{145}$ If a claimant accepts the recommendation, he or she is expected to accept the implementation of the full and final settlement of his claim. SAP ToR, paras. 10, 11.

${ }^{146}$ Holocaust (Return of Cultural Objects) Act 2009.
} 
heard by the SAP before 2009 prohibited the Boards of Trustees of the institutions in question from actually restituting the objects. In these cases the SAP had to resort to a monetary award, by way of a so-called ex gratia payment to express a moral rather than a legal obligation. ${ }^{147}$ The Holocaust (Return of Cultural Objects) Act 2009 now puts discretionary power into the hands of these Boards of Trustees in the event of a recommendation for restitution by the SAP and subsequent approval by the secretary of state. ${ }^{148}$ The norms contained in the SAP's Terms of Reference do not prohibit consideration of the public interest. Up until the present, however, the SAP has repeatedly confirmed that an object's importance to the national collections cannot be a paramount consideration in advising on a restitution request. If it were, it "would almost certainly defeat any claim for restitution against any of the national collections within our remit, and thus frustrate the Panel's primary role as laid down in our terms of reference." ${ }^{149}$ In short, according to the SAP, an emphasis on the public interest would call into question the "very principle of restitution of important works." 150

Clearly, this comparative perspective in terms of the substantive assessment frameworks displays a variety of choices made in regard to the public interest. Both in the Netherlands and Germany, the public interest is included in the assessment of claims. What is different, however, is of course the long-standing Dutch policy and consequent decisions, whereas, in Germany, the public interest has only rather recently and in a single case been included in the Beratende Kommission's reasoning. Additionally, in this recent German case, unlike Dutch cases such as Semmel and Lewenstein, the claimants' interest prevailed. In France, the public interest, via the French system for the protection of cultural heritage, plays a more passive role in the sense that the principle of inalienability may limit the CIVS's leeway in awarding remedies regarding claims on non-MNR objects. In Austria, public interest cannot be invoked against a claimant, and, in the UK, those chances are very slim in light of the SAP's repeated stance in this regard.

Several authors have nevertheless argued that when restitution results in the deaccessioning of objects from public collections, especially when the reinstated owners subsequently sell an object, the public interest can or should be taken into consideration. In such cases, a monetary award might be more appropriate. ${ }^{151}$ Although it is not the aim of this article to stake out a definitive position in this debate, both the Lewenstein/Kandinsky and

\footnotetext{
${ }^{147}$ See SAP ToR para. 17 (c). On the SAP's other remedies see Oost 2018, 155 and extensively, Woodhead 2021, 67-73. In Report of the Spoliation Advisory Panel in Respect of a 12th Century Manuscript Now in the Possession of the British Library, HC 406, 2005, para. 77 (British Library/Benevento Claim), the panel recommended that such legislation be enacted to enable restitution; see para. 7 (a) SAP ToR. For claims where restitution was statute-barred see Report of the Spoliation Advisory Panel in Respect of Four Drawings Now in the Possession of the British Museum, HC 1052, 2006; Report of the Spoliation Advisory Panel in Respect of Pieces of Porcelain Now in the Possession of the British Museum, London and the Fitzwilliam Museum, Cambridge, HC 602, 2008. In the latter case, the award for restitution regarding objects in the Fitzwilliam was not statute-barred. See also Woodhead 2014, 118.

${ }^{148}$ Holocaust (Return of Cultural Objects) Act 2009, Art. 1. Since 2015, the Act is flanked by an Open General Export License, which now includes the category of objects dealt with by the SAP. This means that claimants now no longer have to apply for an individual export license after they have received a positive advice on restitution and an approval by the state secretary. "Open General Export License (Objects of Cultural Interest)," 12 March 2015, https://www.artscouncil.org.uk/sites/default/files/download-file/Open_general_export_licence_March_2015.pdf (accessed 31 October 2019); Woodhead 2019, 18.

149 British Library/Benevento Claim, 22-23, 71.

150 SAP Report on Constable, 11, 46.

${ }^{151}$ Charlotte Woodhead has repeatedly argued that the public interest could be relevant when there is a strong public interest in retaining the objects for the national collection. Woodhead 2014, 131; 2016, 249-50. For similar arguments in the Dutch context, see Lubina 2009, 470-71; Evelien Campfens, "Nederland gaat gewetensvol om met roofkunst," NRC, 18 December 2019.
} 
Semmel cases illustrate the difficulties that arise when the public interest is included as a paramount consideration. ${ }^{152}$ The inclusion of the public interest in an assessment framework that is unmistakably connected to the idea of remedying World War II-related past injustices could create the impression that said historic injustices are being haggled over, especially when the public interest outweighs the interest of the claimant, for example, in the presumed absence on the claimant's part of an intimate connection to the object. ${ }^{153}$ When a broadened restitution policy serves as a tool to remedy historic injustices despite the passage of time, it seems odd that this same passage of time ${ }^{154}$ would establish a new equilibrium in which the interest of undoing systematic dispossession occurring in the context of genocide is considered to be of comparable weight to a current interest that was not relevant nor played any part at the time of the dispossession. The inclusion of the public interest as well as the nature of the relationship between the claimant and the object therefore seems to detract from the effort aimed at fundamentally acknowledging the atrocities of the past, despite the passage of time. ${ }^{155}$

\section{The claimants' position in the Netherlands}

To continue with the criticism of the Dutch situation, it should be noted that the RC, after 30 June 2015, has not applied the balance of interest test and thus did not take the public interest into account in its reasoning regarding NK Collection recommendations. ${ }^{156} \mathrm{~A}$ recent case dealt with by the RC might give further cause for a more nuanced take on things. This case is relevant not only in light of the current critique but also from a comparative perspective in light of the SAP's stance on the public interest. The RC awarded restitution in 2019 in the claim of the heirs of Herbert Gutmann, invoking the criticized yardstick of reasonableness and fairness. In 2010, the same case involving the same heirs yielded a negative recommendation from the SAP.

\footnotetext{
${ }^{152}$ As argued in my lecture of 12 November 2019, “From ‘Leader to Pariah’? On the Dutch Restitutions Committee and the Inclusion of the Public Interest in Assessing Nazi-spoliated Art Claims," hosted by Queen Mary University School of Law and Institute for Art and Law, available at https://www.uva.nl/en/profile/o/o/t.i.oost/t.i.oost.html (accessed 15 March 2021).

${ }^{153}$ Campfens (2020 at 10-11) pointed out that the interest of the "significance" of the object to the former owner was not only embedded in the Dutch post-World War II system on restoration of rights (Article 27(2) Decree E 100) but also included in Article 16 of US Restitution Law no. 59, suggesting that weighing of interests as such was a common phenomenon in the immediate post-World War II framework. When focusing on the Dutch context and the wording of Article 27 of Decree E100 in its entirety, however, this may be read differently. Based on Article 27(1), the Council for Restoration of Rights can award restitution unless the current possessor can prove a good faith acquisition and paid a purchase price for it. This would mean that a good faith acquisition by a museum could be held against the dispossessed owner. Article 27(2) E 100 than continues to say that, even when a current possessor can prove good faith and payment of a purchase price, the Council "can" still award restitution "when the object or right is of considerable greater value for the [original] owner than for the [current] possessor." Therefore, on the basis of Article 27, the explicit weighing of interests came into play in case of plausible good faith acquisitions. In those cases, the greater value of the object for the owner could be asserted in her or his favour and outweigh a good faith acquisition, which is different under the current Dutch policy framework.

${ }^{154}$ On historical injustices, the ethics of time, and, particularly, the difficulties of retrospective politics, see generally Bevernage 2012, 1-19.

${ }^{155}$ See also critically Veraart where he argues that, when restitution is used as restorative effort between a human subject and a cultural object, the nature of this relation itself - the personal value of the object for the heir should not be used as a separate criterion. Veraart 2019, 5 .

156 And thus lived up to the "promise" made by its chair in 2015. See Kohnstamm Committee 2020, 27. For the promise of the RC's chairman in 2015, see the foreword by the Chairman Willibrord Davids in Advisory Committee on the Assessment of Restitution Applications for Items of Cultural Value and the Second World War 2015, 5-6; For an example in this regard, see Lierens Recommendation, which concerned a request involving two NK objects filed after July 2015.
} 
The differing results in the Gutmann case will be discussed below, along with a few other Dutch cases on the basis of which one could easily argue that one is better off at the RC than at the SAP.

\section{Comparing the Herbert Gutmann claims}

In 2010, the SAP dealt with a claim from the heirs of Herbert Gutmann, a renowned Jewish banker/art collector, concerning an oil sketch entitled Coronation of A Virgin by Peter Paul Rubens, in the collection of the Courtauld Institute. ${ }^{157}$ The financial crisis of 1931 affected Gutmann severely. His own Deutsche Orientbank was subsumed by the Dresdner Bank, where he was also a board member, and the Dresdner Bank was nationalized in 1931 due to the crisis. Gutmann was fired that same year and lost his income while being substantially in debt to the selfsame Dresdner Bank. ${ }^{158}$ Once the Nazis came to power in 1933, the Dresdner Bank was Aryanized.

The case centered on the question whether Gutmann's decision to auction off his art collection in 1934 had been forced by the Nazi regime. The SAP answered this question in the negative. According to the SAP, the debts to the Dresdner Bank had already accrued by the time the Nazis came into power, which caused Gutmann to sell his art collection. The demand for repayment of Gutmann's debt was not thought to have any Nazi connotations, as other shareholders of the bank, including an "Aryan," had received demands for similar amounts of money. ${ }^{159}$ The SAP did acknowledge that Gutmann lost his earnings as a result of Nazi anti-Semitism but concluded that this was not the primary motivating factor for the sale of his art collection. ${ }^{160}$ The SAP, therefore, concluded that the moral "strength" of the claimant's case was "insufficiently strong" to award restitution. ${ }^{161}$

On 14 October 2019, the RC issued a positive recommendation for the restitution of objects that had been lost under identical circumstances. ${ }^{162}$ The claimed objects covered by the RC's recommendation were 14 pieces from a Meissen porcelain service that had been acquired by the Dutch state after World War II via a regular sales procedure, then becoming part of the Dutch National Art Collection. ${ }^{163}$ Based on the unification of the Dutch policy, the claim was reviewed on the basis of the principles of reasonableness and fairness. Therefore, the Dutch minister argued that the importance of the objects to the Netherlands consisted of their exceptional quality and uniqueness, with an emphasis on their "historic topographical significance." ${ }^{164}$ In regard to the position of the claimants, much of the RC's recommendation was devoted to the circumstances of the loss. In this context, the RC referred to the

\footnotetext{
${ }^{157}$ Report of the Spoliation Advisory Panel in Respect of an Oil Sketch by Sir Peter Paul Rubens, "The Coronation of the Virgin," Now in the Possession of the Samuel Courtauld Trust, HC 655, 15 December 2010 (Courtauld Institute/ Gutmann Claim).

${ }^{158}$ These debts primarily consisted of Gutmann's participation in the so-called Dresdner Bank Aktien-Syndikat, and his guarantee to an Egyptian cotton fund, which amounted to speculation on the price of Egyptian cotton by means of future contracts.

${ }^{159}$ Courtauld Institute/Gutmann Claim, 52.

${ }^{160}$ According to the SAP, Gutmann lost 80 percent of his income before the Nazis came to power, which was primarily due to personal liability in connection with an Egyptian Cotton Fund as well as a syndicate and the detrimental effects of the financial crisis on these ventures. The SAP acknowledged that the loss of Gutmann's income between 1933 and 1934 was caused by Nazi persecutory measures but only amounted to 20 percent of his income. Courtauld Institute/Gutmann Claim, 14, 73.

${ }^{161}$ Or any other remedy. Courtauld Institute/Gutmann Claim, 17, 90.

162 Recommendation Regarding Herbert Gutmann, RC 1.157, 14 October 2019 (Gutmann Recommendation).

163 Objects were on display in Het Loo Palace, the Rijksmuseum, and the Zuiderzeemuseum. Gutmann Recommendation, 16.

${ }^{164}$ Gutmann Recommendation, 22.
} 
Ekkart Committee's recommendations on the reversal of the burden of proof for private Jewish individuals in Germany from 1933, barring evidence to the contrary. According to the RC, there was no such evidence in the Gutmann case. Contrary to the SAP's advice, the RC held that Gutmann's decision to sell had been involuntary "due to circumstances directly related to the Nazi regime." Interestingly, the RC held that there was already evidence of Nazi targeting of Herbert Gutmann before 1933, referring to a 1932 Nationalsozialistische Deutsche Arbeiterpartei's election pamphlet that evidenced that "Gutmann was publicly pilloried for his role in the 1931 banking crisis because of his Jewish descent."165

This assumption was important to the RC's different weighing of the available evidence and facts related to Gutmann's debts. For one, the fact that the Dresdner Bank was nationalized in 1931 meant that the Nazis had "rapidly acquired major influence" over the Dresdner Bank, thus putting Gutmann in a "vulnerable position" due to his debts to the bank and the Nazi's labeling him as one of the persons responsible for the 1931 bank crisis. Furthermore, the RC found evidence that Gutmann's debts were at least partially "fabricated - documents were found indicating that the Dresdner Bank had initially calculated Gutmann's share of debt to be four times higher than it should have been and there was no indication of a subsequent correction. Additionally, it could be "deduced from the available documents" that, although Gutmann had enough possessions to cover his debts at the time, he was not allowed to sell them. Finally, whereas the SAP held that Gutmann and the "Aryan" shareholder were treated equally with the demand to repay the debts, the RC found that this was not the case. According to the RC, the "Aryan" shareholder was offered a favorable repayment arrangement by the Dresdner Bank. Among other things, the "Aryan" shareholder was granted a payment postponement, only needed to repay part of his total debt to the bank, and was given years to do so. ${ }^{166}$ Gutmann's decision to auction off the objects should therefore be considered a forced sale "in accordance with the Ekkart Committee's third recommendation."

The RC then emphasized that it was obliged to issue a recommendation on the basis of the yardsticks of reasonableness and fairness. In weighing up the interests, however, "very great weight [was] given to the way in which possession was lost and to the need to right wrongs committed during and as a result of, the Nazi regime," which outweighed the state's interest in retaining them. ${ }^{167}$ Lastly, Gutmann did use the proceeds of the sales to pay off his debts to Dresdner Bank, but the RC did not attach a condition for repayment of the sales proceeds to the award of restitution. Gutmann's debt had been exaggerated by a factor of four, meaning that it could not be assumed that the proceeds were disposed of freely. ${ }^{168}$

\section{The claimants' position as reflected in recent Dutch cases: A “step back" indeed?}

One cannot draw definitive conclusions based on one or even a handful of cases. ${ }^{169} \mathrm{~A}$ comparison of these two cases, however, does suggest that a conclusion to the effect that

\footnotetext{
${ }^{165}$ Gutmann Recommendation, 27.

166 Gutmann Recommendation, 30.

${ }^{167}$ Gutmann Recommendation, 33. It is again noted here that the minister announced on 12 March 2021 that in future claims neither the public interest nor good-faith acquisition shall be asserted for objects in the Dutch National Art Collection. Letter of the Minister to the Lower House 2021, 4.

${ }^{168}$ Gutmann Recommendation, 34.

${ }^{169}$ It is noted here that in the claims of the Oppenheimer heirs also yielded different results at the SAP and the Dutch RC. Woodhead $(2019,34)$ recently suggested that this might be related to advanced provenance research. Woodhead. Eric Idema, secretary to the Dutch RC indeed confirmed that the documents referred to in the SAP's advice were most likely not known to the Dutch RC (44). Given the relaxed governmental guidelines and the fact that the Oppenheimers themselves were absent when the objects were sold and were almost immediately subjected to Nazi persecutory measures, it remains to be seen whether the Dutch RC's recommendations would have yielded a
} 
the Dutch restitution policy has lost sight of the victims' perspective is not entirely justified. The generous governmental guidelines, which aimed to facilitate former owners and their heirs, continue to reverberate through the recommendations of the RC. ${ }^{170}$ In the case of the Gutmann heirs, this led to a rather unequivocal and novel emphasis on the need to right wrongs, with the RC even widening the scope of the government guidelines by taking the course of events before 1933 into consideration when deciding on the involuntariness of the loss of Gutmann's possessions.

The reasoning in the Gutmann case is not an anomaly if one considers other similar recent cases such as the binding opinion in the claim of the Kirstein heirs, a German family of Jewish descent. That claim concerned a Max Liebermann drawing that featured a Jewish neighborhood in Amsterdam. ${ }^{171}$ The claimed object was owned by the Amsterdam municipality, and, like Lewenstein/Kandinsky, the case was decided on the basis of the principles of reasonableness and fairness. Although it could not be established with absolute certainty that the claimed object was still in the possession of the Kirstein family at around the time of the loss in 1939 - let alone the exact fate of the object in terms of how and when it had been lost - the claimants prevailed. ${ }^{172}$ In the absence of any indication that the Kirstein family had themselves sold the object, greater weight was given to the evidence of the family's persecution under the Nazis starting in 1938 (when the family's publishing business was placed under the control of a Nazi administrator). ${ }^{173}$ The RC considered it "sufficiently plausible" that the object had been lost due to circumstances directly related to the Nazi regime, expressly referring to Washington Principle IV, which, for the assessment of such claims, makes a plea for consideration of any "unavoidable gaps or ambiguities in provenance." ${ }^{174}$ The RC concluded that restitution should be granted since "considerable weight" should be given to the heirs' interests despite the public interest argued by the Amsterdam municipality in keeping the object due to its unique subject matter in light of Amsterdam's Jewish history. ${ }^{175}$

different, and thus negative, advice for restitution. For the SAP's advice, see Bristol City Council/Oppenheimer Claim. The Dutch RC issued three recommendations and one binding opinion, see Recommendation Regarding Oppenheimer, RC 1.67, 4 February 2008; Recommendation regarding Oppenheimer II, RC 1.120, 7 June 2011; Recommendation Regarding Oppenheimer III, RC 1.133, 8 April 2013; Binding Advice Concerning the Dispute over the Painting Road to Calvary, RC 3.95, 3 May 2010; email from Eric Idema, 28 May 2020 (on file with the author).

${ }^{170}$ As highlighted earlier, the RC has not applied the balance of interest test in cases concerning the NK Collection; Kohnstamm Committee 2020, 27.

${ }^{171}$ Binding Opinion Regarding the Dispute about Restitution of the Drawing Jewish Quarter in Amsterdam, by Max Liebermann, currently in the possession of Amsterdam City Council, RC 3.172, 16 April 2019 (Kirstein/Amsterdam City Council Claim).

${ }_{172}$ The last record of the painting being in the possession of the Kirstein family dates from 1923. On the basis of the available documentation, it could be concluded that the Kirstein collection was sold or offered for sale on various occasions in the course of 1939. It remains unclear when the claimed object was sold. Kirstein/Amsterdam City Council Claim, 3.2, 3.3, 3.4, 3.7, 3.8 and 6.2.

${ }^{173}$ Added by several indicators suggesting that the family did not indeed sell the objects. There was no evidence of personal financial difficulties, a statement by the family's former secretary that the family's art collection remained intact until 1939, and an inventory list from the auction house that was involved in selling at least part of the family's art works in that time frame. See Kirstein/Amsterdam City Council Claim, para. 6.2.

${ }^{174}$ See Washington Principles, Principle IV, referring to the "unavoidable gaps or ambiguities in the provenance in the light of the passage of time and the circumstances of the Holocaust Era." Kirstein/Amsterdam City Council Claim, para. 6.2.

${ }^{175}$ In the latest binding opinion issued by the RC, prior to the Kohnstamm Committee's report, the Rotterdam City Council expressed its explicit wish not to invoke a weighing of interests and did not assert the public interest in the case. The RC consequently refrained from a weighing of interests and settled the case based on its conclusion on the involuntariness of the loss. Binding Opinion Regarding the Dispute about the Return of a Bronze Situla and a Bronze Candelabrum, Currently in the Possession of Rotterdam City Council, RC 3.180, 13 July 2020, 4.2, 6.5. Kohnstamm Committee 2020,34. This position tallies well with the recent developments where it seems unlikely 
One could easily argue, in light of the Liebermann case, that the disparate treatment of the Gutmann claim by the SAP and the RC hinges on the more favorable consideration accorded to the claimants' position in the Netherlands since the founding of the RC in 2001. Here, the contrasting assessments of the two panels about 10 years ago in the case about the art collection of Kurt Glaser can serve as an illustration. ${ }^{176}$ Although the SAP concluded that Nazi persecution was the predominant motive, it was not decisive. The "causation" argued by the Courtauld Institute was considered more convincing. ${ }^{177}$ Particular weight was given to Glaser's letter to his friend, the famous artist Edvard Munch, in May 1933, in which Glaser attributed his decision to sell his art collection not only to Nazi persecutory measures resulting not only in the loss of his office and eviction but also to his desire to start a new life after the death of his wife. ${ }^{178}$ Also, whereas the heirs argued the involuntariness of the loss in part based on the fact of the German monetary compensation received post-World War II, the SAP felt that the sales proceeds of the auctions accurately reflected the prevailing market prices at the time. ${ }^{179}$ In the Netherlands, the Glaser claim concerned an object from the NK Collection, which meant that the case was dealt with based on the generous government guidelines. Since Glaser sold his collection in Germany after 1933, this meant the reversal of the burden of proof, and, thus, the sale was considered involuntary. Contrary to the SAP, the RC did not conclude that there was evidence "expressly" proving otherwise. ${ }^{180}$ Neither did the monetary compensation received post-World War II constitute an impediment to restitution since the settlement was not considered to be a waiver of the rights to the lost objects and the Dutch state was not a party to the settlement. ${ }^{181}$ Hence, the $\mathrm{RC}$ issued a recommendation for restitution.

\section{Conclusion}

The establishment of the RC in 2001 was a decision motivated by the wish to facilitate claimants who would most likely come up empty-handed if their cases were approached in strictly legal terms. Motivated by a new victim group-oriented approach in which the emphasis was on righting extreme wrongs of the past as grounds to supersede legal barriers, the Dutch government decided to provide the opportunity to once again claim objects that

that the municipality of Amsterdam (and other lower governments) will advance such arguments in future cases. Letter of the Board of Mayor and Aldermen 2021; Letter from the Minister to the Lower House 2021, 4.

${ }^{176}$ For the Dutch RC's case, see Recommendation Regarding Glaser, RC 1.99, 4 October 2010 (Glaser Recommendation). For the SAP's advice, see Report of the Spoliation Advisory Panel in Respect of Eight Drawings Now in the Possession of the Samuel Courtauld Trust, HC 757, 24 June 2009 (Courtauld Institute/Glaser Claim). On these differences and further references also, see Oost 2018, 161-63.

177 Courtauld Institute/Glaser Claim, 7, 37.

${ }^{178}$ It was also relevant that Glaser managed to transport some of his art works to Switzerland between 1933 and 1939. For the quotation of the letter included in the SAP's advice, see Courtauld Institute/Glaser Claim, 3, 16. The passage most relevant for the assumption of a predominantly voluntary sale is reproduced here: "Since the death of my wife the whole world of my past has gradually crumbled ... until there was nothing left. It started with something apparently quite trivial, the death of my dog. For me this was a sign from which the rest ensued. I had to give up my apartment, I lost my position. Since I found it pointless to rent a large new home at this point, I have freed myself of all my possessions, so that I might start over again completely new" (emphasis added).

${ }^{179}$ From the claimants' side, a discussion on the received sales proceeds was not considered necessary as they relied entirely on the post-World War II testimonies by Glaser's widow and her sister-in-law made in relation to the 1963 post-World War II compensatory settlement as proof of the sales at an undervalue. Courtauld Institute/Glaser Claim, 5, 28.

${ }^{180}$ Glaser Recommendation, para. 6.

${ }^{181}$ In contrast, the post WW II compensation was one of the factors in the SAP's case that led to the conclusion that the claim of the Glaser heirs was "insufficiently strong to warrant a recommendation" for the return of the object. Courtauld Institute/ Glaser claim, 7-8, 43 and 47. 
had been long since involuntarily lost. It appears, however, that current critique is rooted in that same new paradigm, which paved the way for addressing the issue of Nazi-looted art in the first place. Over time, the way in which this deliberate choice was constructed in the Netherlands became a source of confusion. For the most part, this confusion resulted from the well-intentioned choice for a generous approach, resulting in two separate assessment frameworks. The choice for low-threshold and flexible proceedings to facilitate claimants resulted in a changing set of applicable substantive rules, which over time made the Dutch restitution policy and its RC vulnerable to critique. Changing the rules of the game in the Netherlands has brought about a lack of clarity regarding the predictability of the outcome of the procedure. ${ }^{182}$ The fact that these changes incidentally work to the disadvantage of the claimant has only reinforced this critique.

The 2012 unification of policy failed to provide the desired clarity, as demonstrated by the recent Lewenstein/Kandinsky case and consequent developments. Again, as in the case of the Semmel heirs in 2013, the legitimate aim of the RC was - and still is - publicly questioned, primarily because of the inclusion of the public interest in the applicable assessment framework. ${ }^{183}$ Although the inclusion of the public interest in the assessment framework and the current application thereof by the RC, both from a comparative view as well as from a more principled stance, may give reason to doubt the fairness of the Dutch policy framework, the Lewenstein/Kandinsky case was a highly complex case to begin with. There were just too many inconclusive aspects to this case, which made it impossible for the RC to construct a chain of plausible inferences in the absence of hard evidence. A simple answer to the effect that the circumstances of the loss of possession were too vague, in this case, to render a positive decision on restitution might have been more satisfactory to all parties involved.

Also, the comparative view as applied to the Gutmann claim and the Glaser cases, which yielded different results at the SAP and the RC, and the other RC cases cited in this article, suggest a more nuanced conclusion on the merits of the Dutch policy. On the contrary, the Dutch policy rules and their application by the RC - for example, the presumption of involuntary loss - indicate a more favorable approach to claimants in comparison to the English model. This is interesting given that the SAP has repeatedly refused to consider the public interest a paramount factor, as it would otherwise infringe on the very principle of restitution. Therefore, it remains to be seen whether one can indeed fully substantiate the "step-back" criticism. One thing is clear: the Dutch policy as it now stands reveals a certain vulnerability, which is primarily due to its rather "lightweight" and flexible institutional framework. The victim's perspective is still taken into account by the RC, but the patchwork of applicable substantive rules easily clouds a more nuanced conclusion. That said, changing the rules of the game, even with proper motivation, has led to a sense of arbitrariness, and raises questions about the legitimacy of the undertaking, as such. It seems therefore that the current discussion primarily demonstrates the downfalls of a policy that is entirely based on flexible policy rules. ${ }^{184}$ The resulting vulnerability affects the legitimacy of the Dutch policy framework's aim to provide just and fair solutions with due consideration of the claimant's perspective.

Acknowledgements. This article is based on the lecture by Tabitha I. Oost, "From "Leader to Pariah"? On the Dutch Restitutions Committee and the Inclusion of the Public Interest in Assessing Nazi-spoliated Art Claims," Queen Mary

\footnotetext{
182 Oost, "Maak de Restitutiecommissie minder kwetsbaar."

${ }^{183}$ Although the announced "renewed" framework where the public interest and the weighing of interests is largely excluded may be applauded in view of the victim's perspective, due to the yet again phased response the situation still remains unclear and fits squarely with the ad hoc nature of the Dutch government's approach on the issue of Nazi-looted art as described in this article. Letter from the Minister to the Lower House 2021, 6.

${ }^{184}$ Oost, "Maak de Restitutiecommissie minder kwetsbaar."
} 
University School of Law and Institute for Art and Law Visiting Scholar Lectures in Art Business and Law, 12 November 2019. The author is indebted to Debbie di Girolamo for the opportunity granted as a Visiting Scholar Art Business and Law at Queen Mary University of London. The article has benefited greatly from the peer reviewers' comments. Lastly, I thank those who were of help in earlier drafts, in particular, Anna van Duin, Matthias Weller, and my supervisors Wouter J. Veraart and Jan-Herman Reestman. Any errors or omissions are of course, the author's own.

Author biography. Tabitha I. Oost is the Lalive Merryman Fellow 2019-20 at the Art-Law Centre of the Université de Génève, which was awarded to her on the basis of her article "Restitution Policies on Nazi-Looted Art in the Netherlands and the United Kingdom: A Change from a Legal to a Moral Paradigm?" International Journal of Cultural Property (2018).

\section{Bibliography}

Advisory Committee on the Assessment of Restitution Applications for Items of Cultural Value and the Second World War. 2006. Report 2006. https://www.restitutiecommissie.nl/sites/default/files/Verslag\%202006.pdf (accessed 15 March 2021).

Advisory Committee on the Assessment of Restitution Applications for Items of Cultural Value and the Second World War. 2007. Report 2007. https://www.restitutiecommissie.nl/sites/default/files/Report\%202007.pdf (accessed 15 March 2021).

Advisory Committee on the Assessment of Restitution Applications for Items of Cultural Value and the Second World War. 2008. Report 2008. https://www.restitutiecommissie.nl/sites/default/files/Verslag\%202008.pdf (accessed 15 March 2021).

Advisory Committee on the Assessment of Restitution Applications for Items of Cultural Value and the Second World War. 2012. Report 2012. https://www.restitutiecommissie.nl/sites/default/files/Report\%202012.pdf (accessed 15 March 2021).

Advisory Committee on the Assessment of Restitution Applications for Items of Cultural Value and the Second World War. 2015. Report 2015. https://www.restitutiecommissie.nl/sites/default/files/Report\%202015.pdf (accessed 15 March 2021).

Advisory Committee on the Assessment of Restitution Applications for Items of Cultural Value and the Second World War. 2019. Report 2019. https://www.restitutiecommissie.nl/en/system/files/Report\%202019.pdf (accessed 15 March 2021).

Bazyler, Michael J., and Roger P. Alford. 2006. "Introduction.” In Holocaust Restitution: Perspectives on the Litigation and Its Legacy, edited by Micheal J. Bazyler and Roger P. Alford, 1-13. London: New York University Press.

Bevernage, Berber. 2012. History, Memory and State-Sponsored Violence: Time and Justice. New York: Routledge.

Blimlinger, Eva, and Jabloner, Clemens. 2009. Die Regelung der Kunstrückgabe in Österreich, The Regulation of the Restitution of Artworks in Austria. In Verantwortung wahrnehmen. NS-Raubkunst - Eine Herausforderung an Museen, Bibliothek und Archive, edited by Koordinierungsstelle für Kulturgutverluste, 203-245. Magdeburg: Veröffentlichungen der Koordinierungsstelle für Kulturverluste, Bd. 7.

Campfens, Evelien. 2014. “Alternative Dispute Resolution in Restitution Claims and the Binding Expert Opinion Procedure of the Dutch Restitutions Committee." In Art, Cultural Heritage and the Market, edited by Valentina Vadi and Hildegard Schneider, 61-91. Berlin: Springer.

Campfens, Evelien. 2015. "Sources of Inspiration: Old and New Rules for Looted Art." In Fair and Just Solutions? Alternatives to Litigation in Nazi-Looted Art Disputes: Status Quo and New Developments, edited by Evelien Campfens, 13-40. The Hague: Eleven International Publishing.

Campfens, Evelien. 2017. "Nazi-looted Art: A Note in Favour of Clear Standards and Neutral Procedures." Art Antiquity and Law 22, no 4: 315-47.

Campfens, Evelien. 2020. "Bridging the Gap Between Ethics and Law: The Dutch Framework for Nazi-Looted Art." Art Antiquity and Law 25, 1: 1-24.

Casini. Lorenzo. 2011. “Italian Hours': The Globalization of Cultural Property Law." International Journal of Constitutional Law 9, no 2: 363-93.

Den Hollander, Pieter. 2007. Roofkunst. De Zaak Goudstikker. Amsterdam: J. M. Meulenhoff BV.

Dewey, Anne. 2020. Gerecht und fair? "Guter Glaube" im Nachkriegsrecht und Lösung gegenwärtiger Raubkunstfälle - Teil 1. KUR - Kunst und Recht 6: 154-159.

Feliciano, Hector. 1995. Le Musée disparu: Enquête sur le pillage des oevres d'art en France par le Nazis. Paris: Austral.

Fisher, Wesley A., and Ruth Weinberger. 2014. Holocaust-Era Looted Art: A Current World-Wide Overview (Sint-Petersburg). http://art.claimscon.org/wp-content/uploads/2014/11/Worldwide-Overview.pdf (accessed 15 March 2021).

Hammerstein, Fred. 2021. "Vier jaar Restitutie(wan?)beleid.” Nederland Juristenblad 6: 439-45. 
Herkomst Gezocht/Origins Unknown. 2006. Eindrapportage Commissie Ekkart/Final Report Ekkart Committee. Zwolle: Waanders Uitgeverij.

Kahl, Arno. 2018. “Artikel 17 B-VG.” In Rill-Schäffer-Kommentar Bundesverfassungsrecht, edited by Benjamin Kneihs, Georg Lienbacher. Vienna: Verlag Österreich.

Kahmann, Henning. 2016. "Dringender Reformbedarf bei der Limbach-Kommission." Zeitschrift für offene Vermögensfragen 1: 8-12.

Kahmann, Henning, and Varda Naumann. 2015. “Anmerkung zur Empfehlung der Beratenden Kommission im Fall 'Behrens ./. Düsseldorf.' Zeitschrift für offene Vermögensfragen 2: 114-19.

Kohnstamm Committee (Committee for the Evaluation of the Restitution Policy for Cultural Heritage Objects from the Second World War). 2020. Striving for Justice, 7 December. https://www.raadvoorcultuur.nl/english/docu menten/adviezen/2020/12/07/striving-for-justice (accessed 15 March 2021).

Le Masne de Chermont, Isabelle, and Didier Schulmann. 2000. Le Pillage de l'art en France pendant l'occupation et la situation des 2000 oeuvres confiées aux musées nationaux. Paris: La documentation Française.

Le Masne de Chermont, Isabelle and Laurence Sigal-Klagsblad, eds. 2008. A qui appartenaient ces tableaux? La Politique Française de Recherche de Provenance, de Garde et de Restitution des Oeuvres d'Art pillées durant la Seconde Guerre Mondiale. Paris: Réunion des musées nationaux.

Lubina, Katja. 2009. Contested Cultural Property: The Return of Nazi Spoliated Art and Human Remains from Public Collections. Maastricht: Self-published.

Marck, Annemarie, and Eelke Muller. 2015. "National Panels Advising on Nazi-Looted Art in Austria, France, the United States, The Netherlands and Germany." In Just and Fair Solutions: Alternatives to Litigation in Nazi-Looted Art Disputes: Status Quo and New Developments, edited by Evelien Campfens, 41-89. The Hague: Eleven International Publishing.

Merryman, John Henry. 1989. “The Public Interest in Cultural Property.” California Law Review 77: 339-64.

Merryman, John Henry, Albert. E. Elsen, and Stephen K. Urice, 2007. Law, Ethics and the Visual Arts 5th ed. Alphen aan den Rijn: Kluwer Law International.

Muller, Eelke. 2001. “'Gestolen Joodsch Bezit”. De verdwenen kunstcollectie van de familie Zoellner.' Jong Holland, 17, no. 2: 25-38.

Neumann, Klaus, and Janna Thompson. 2015. "Introduction: Beyond the Legalist Paradigm." In Historical Justice and Memory, edited by Klaus Neumann and Janna Thompson, 3-26. Madison: University of Wisconsin Press.

Noll, Alfred J. 2011. Abnehmende Anwesenheit. Ein Pamphlet zur Kunstrückgabe in Österreich. Vienna: Czernin Verlag.

Nicolas, Lynn. 1994. The Rape of Europe: The Fate of Europe's Treasures in the Third Reich and the Second World War. London: MacMillan.

O’Donnell, Thérèse. 2010. “The Restitution of Holocaust Looted Art and Transitional Justice: The Perfect Storm or the Raft of Medusa?” European Journal of International Law 22, no. 1: 49-80.

Oost, Tabitha I. 2012. In an Effort to Do Justice: Restitution Policies and the Washington Principles. Amsterdam: Centre for Art Law and Policy.

Oost, Tabitha I. 2018. "Restitution Policies on Nazi-Looted Art in the Netherlands and the United Kingdom: Change from a Legal to a Moral Paradigm?" International Journal of Cultural Property 25, no 2: 139-78.

Palmer, Norman. 2000. Museums and the Holocaust: Law, Principles and Practice. Leicester: IAL Publishing.

Peters, Robert. 2012. "Remedying Historical Injustice: Ethical and Historical Considerations in Returning Cultural Materials." In Cultural Heritage, Cultural Rights, Cultural Diversity: New Developments in International Law, edited by Sylvia Borelli and Frederico Lenzerini, 141-56. Leiden: Nijhoff.

Petropoulos, Jonathan. 1996. Art as Politics in the Third Reich. Chapel Hill: University of North Carolina Press.

Trenkler, Thomas. 1999. Der Fall Rothchild. Chronik einer Enteignung. Vienna: Czernin Verlag.

Unfried, Berthold. 2014. Vergangenes Unrecht, Entschädigung und Restitution in einer globalen Perspektive. Göttingen: Wallstein.

Veraart, Wouter. 2005. Ontrechting en rechtsherstel in Nederland en Frankrijk in de jaren van bezetting en wederopbouw. Rotterdam: Sanders Instituut and Kluwer.

Veraart, Wouter. 2010. De passie voor een alledaagse rechtsorde. Over vergeten, herinneren en vergeven als reacties op historisch onrecht. The Hague: Boom Juridische uitgevers.

Veraart, Wouter. 2016. "Two Rounds of Postwar Restitution and Dignity Restoration in the Netherlands and France." Law \& Social Inquiry 41, no. 4: 956-72.

Veraart, Wouter. 2019. "Beyond Property. A Reflection on the Value of Restitution of Looted Cultural Objects." Social Sciences Research Network. https://ssrn.com/abstract=3524852 or http://dx.doi.org/10.2139/ssrn.3524852 (accessed 15 March 2021).

Weller, Matthias. 2015. "Key Elements of Just and Fair Solutions: The Case for a Restatement of Restitution Principles.' In Just and Fair Solutions: Alternatives to Litigation in Nazi-Looted Art Disputes: Status Quo and New Developments, edited by Evelien Campfens, 201-12. The Hague: Eleven International Publishing. 
Weller, Matthias. 2017. “Gedanken zur Reform der Limbach Kommission.” Kunst und Recht 19, no. 5-6: 136-44.

Woodhead, Charlotte. 2013. "Nazi-Era Spoliation: Establishing Procedural and Substantive Principles.” Art Antiquity and Law 18, no. 2: 167-93.

Woodhead, Charlotte. 2014. "Redressing Historic Wrongs, Returning Objects to Their Rightful Owners or Laundering Tainting Objects? 21st-Century UK Remedies for Nazi-Era Injustices." International Journal of Cultural Property 21, nos. 2-3: 113-42.

Woodhead, Charlotte. 2016. "Putting into Place Solutions for Nazi Era Dispossessions of Cultural Objects: The UK Experience." International Journal of Cultural Property 23, no. 4: 385-406.

Woodhead, Charlotte. 2019. Implementing Recommendation 3 of the 2017 London Conference Action Plan, March 2019, revised October 2019. https://assets.publishing.service.gov.uk/government/uploads/system/uploads/attach ment_data/file/862067/Woodhead_Recommendation_3_FINAL_report_October_2019.pdf (accessed 15 March 2021).

Woodhead, Charlotte. 2021. "United Kingdom" In: Museums and the Holocaust, edited by Ruth Redmond-Cooper, 51-73. London: Institute for Art and Law.

Zivie, David. 2018. “Des traces subsistent dans des registres..." Biens culturels spoliés pendant la Seconde Guerre mondiale: une ambition pour rechercher, retrouver, restituer et expliquer. Paris: Ministère de la Culture. https://www.culture. gouv.fr/Espace-documentation/Rapports/Rapport-de-David-Zivie-Des-traces-subsistent-dans-des-registresBiens-culturels-spolies-pendant-la-Seconde-Guerre-mondiale-une-ambition-pou (accessed 15 March 2021).

Cite this article: Oost, Tabitha I. 2021. "From "Leader to Pariah"? On the Dutch Restitutions Committee and the inclusion of the public interest in assessing Nazi-spoliated art claims." International Journal of Cultural Property 28, no. 1: 55-85. https://doi.org/10.1017/S0940739121000072 